\title{
Subject marking in Awing ${ }^{1}$
}

\author{
Henry Fominyam \& Doreen Georgi \\ University of Potsdam
}

\begin{abstract}
This paper investigates the principles that govern subject marking in Awing (Grassfields Bantu). We observe that the subject marker (SM) that doubles the subject is sometimes obligatory, sometimes optional and sometimes prohibited. We argue that it is the referentiality of the subject that controls the distribution of the SM in Awing, rather than factors such as its morpho-syntactic features or its information structural status, which have been identified to govern argument doubling in a number of other languages with a similar phenomenon. The empirical evidence leads us to conclude that the SM is a pronominal element in Awing rather than an agreement marker. When it occurs, it functions as the argument of the verb and the associated subject NP is base-generated in the left periphery of the clause; when it is absent, the NP is the verbal argument. Awing thus qualifies as a pronominal argument language in the sense of Jelinek (1984); Bresnan and Mchombo (1987); Baker (1996).
\end{abstract}

Keywords: argument encoding, doubling, pronominal argument languages, referentiality, Grassfields Bantu

\section{Introduction}

This paper investigates the principles that govern subject marking in Awing, an Eastern Grassfields Bantu language spoken in North-Western Cameroon by about 31.000 speakers. There is very little descriptive or formal work on Awing: Alomofor (2007) is an Awing-English dictionary and Azieshi (1994); van der Berg (2009) provide basic phonological information about the language. More recently, Fominyam (2015); Fominyam and Šimík (2017) offer studies of the syntax of interrogative clauses and focus marking, respectively. Mucha and Fominyam (2017) investigate the semantics of tense in the language. The present paper adds a discussion of subject marking, a topic only briefly mentioned in Fominyam and Šimík (2017). Unless citations are provided, the Awing data in this paper are novel and come from the first author, who is a native speaker of the language. Awing has basic SVO word order in declarative all-new sentences. It exhibits a noun class system and has rich agglutinating verbal morphology that expresses TAM-categories and derivational processes. Awing is a tone language that distinguishes between high (á), low (a, unmarked), rising ( $\breve{a})$ and falling (â)

\footnotetext{
${ }^{1}$ For comments and discussion of previous versions of this paper we would like to thank the audiences at ACAL 50 (UBC, May 2019) and the DISCO workshop (Leipzig University, May 2019), Radek Šimík, and two anonymous reviewers. This research was funded by the Deutsche Forschungsgemeinschaft (DFG, German Research Foundation) - Project ID 317633480 - SFB 1287, Project C05 (Georgi).
} 
tones. Tones distinguish lexical and grammatical information. (1) provides two examples that illustrate these basic properties: $:^{2,3}$
Alombah (a) pə’ m-má m-bí n-naynə məzíə
Alombah SM PST N-NEG N-ITER N-cook food
'Alombah did not cook the food again.'

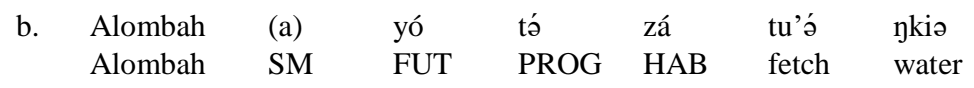
'Alombah shall often be fetching water.'

What we are interested in is the Awing subject marker (abbreviated and glossed as SM in what follows) that doubles the subject. Its form reflects number (singular, plural) and animacy (human vs. non-human) of the subject, see the paradigm in (2). With non-human plural subjects the exponent ( $p$ a vs. $m a$ ) is also sensitive to semantic aspects of the noun, but we will not discuss this distinction further in this paper. ${ }^{4}$ In (1) the SM surfaces as a since the subject Alombah (a proper name) refers to a singular human being. All SM forms are illustrated in (3).

Awing SM paradigm:

\begin{tabular}{|l|l|l|}
\hline & Human & Non-human \\
\hline sg & a & ว́ \\
\hline pl & po & pə, mə \\
\hline
\end{tabular}

(3)
a. Alombah (a) nə n-náynə məzíə
Alombah SM PST N-cook food
'Alombah cooked food.'

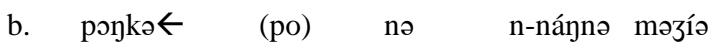
children SM PST N-cook food
'The children cooked food.'
c. tésćləsćlə (á) nə n-dumə Tsefor
soldier_ant.SG SM PST N-bite Tsefor
'A soldier ant bit Tsefor'

\footnotetext{
${ }^{2}$ Awing distinguishes between three past and three future markers; they differ in remoteness, viz. they express whether the action happened/will happen on the same day, in the same week or year. We do not gloss these differences in this paper, only past and future, because the distinction is not relevant for subject marking. The noun class system has not been completely worked out since Awing is an understudied language: it is in progress (Alomofor \& Akem in prep). As far as we can tell based on the available information, the class membership of a noun does not influence the distribution of the SM, the main subject of this paper.

${ }^{3}$ The nasal prefix (glossed as $\mathrm{N}$ ) that occurs in some of the Awing examples in this paper is triggered by tense/aspect morphemes (except for the future marker, see (1-b)) on all following verbal elements in the clause, i.e., on other tense/aspect morphemes, on negation markers and on the lexical verb. In (1-a), for example, it is triggered by the past tense morpheme $p e$ '. The nasal assimilates its place of articulation to the following consonant. This element is attested in other Grassfields Bantu languages, too (see Tamanji 2009 on Bafut) but its function is still debated; see Fominyam (in prep.) for discussion of the prefix in Awing. Its presence or absence does not interact with subject marking in Awing in any way.

${ }^{4}$ Roughly, the semantic aspects that seem to play a role for the choice between the two plural non-human exponents are whether the subject denotes clearly individuated atomic or non-atomic entities. We leave it to future research to determine the factors involved more precisely.
} 


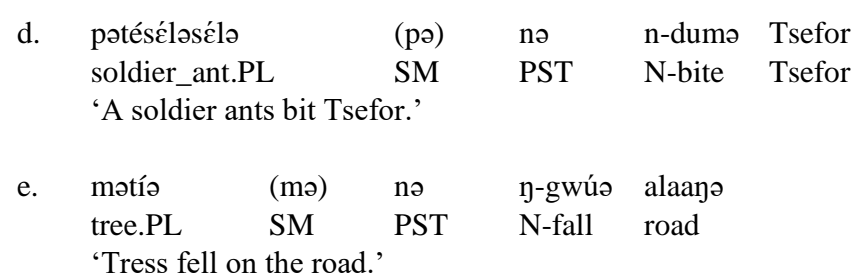

Crucially, the occurrence of the SM in Awing is variable: In some sentences it is optional (as in all previous examples, indicated by the brackets), in others it is prohibited, see e.g., the subject question in (4-b), and in some it is obligatory (to be discussed below).
a. Alombah
(a)
nə
n-nánnə məzí
əzooná
Alombah SM PST N-cook food yesterday
'Alombah cooked the food yesterday.'
b. wə (*a) nə n-nánn məzí əzooná
who SM PST N-cook food yesterday
'Who cooked the food yesterday?'

The aim of this paper is to explore what governs the distribution of the SM in Awing, i.e., to find out which factors determine when it can or must (not) occur.

That subject marking devices can or even must be absent or change their form in certain contexts, especially in subject A'-dependencies like questions, is a well-known phenomenon in the languages of the world, also in the rather closely related Bantu languages (see among many others Bresnan and Mchombo 1987; Baker 2003; Schneider-Zioga 2007; Diercks 2010; Henderson 2013). The triggers for the drop of the SM or the change of its morphological shape that have been identified for most Bantu languages with this phenomenon are (a) the information structure status of the subject (focal), (b) it's A'-relatedness (viz., occupying an A'-position or bearing an A'-feature), and (c) the pronominal nature of the marker. The question is whether SM drop in Awing is conditioned by any of these factors, too. We provide evidence that (a) and (b) are irrelevant to subject marking in Awing. Instead, we observe that the referentiality of the subject is crucial. Only referential subjects can be doubled by the SM in Awing, non-referential ones must not be doubled. This and other observations lead us to conclude that the SM is a pronominal clitic in Awing, see trigger (c). Furthermore, we provide evidence that referential subject NPs can optionally occur in a position at the left edge of the clause, while non-referential ones must occupy the canonical (derived) subject position SpecT. When the SM is present, it is in fact the thematic argument of the verb and the associated subject NP can only be a base-generated adjunct in the left periphery of the clause. Since non-referential NPs are incompatible with such a position, they can only be used when they are the thematic argument of the verb themselves, i.e., when the SM is absent. This leads to obligatory SMdrop with non-referential subjects. In a nutshell, we claim that Awing is a pronominal argument language and hence its SM-system is similar to those found, e.g., in Native American languages as well as in Bantu languages, especially for object marking (see Bresnan and Mchombo 1987; Baker 2003).

The paper is structured as follows: Section 2 argues against information structure and antiagreement-based approaches to SM-drop in Awing; furthermore, we provide evidence for the crucial role of referentiality in subject marking in Awing. Section 3 presents the formal analysis as well as empirical support for the pronominal status and the left-adjunction of SM doubled subject NPs. In Section 4 we discuss why personal pronouns cannot be doubled by the SM. Section 5 concludes. 


\section{Conditions on subject marking}

In an information-structurally (IS) neutral declarative sentence, as e.g., in (4-a), the SM in Awing is optional (to be refined below). A context in which it is obligatorily dropped, however - and the one where this is most easily detectable for speakers - is in subject questions as in (4-b). Interestingly, a change in argument encoding morphology, be that an entire loss of it as in Awing, or at least a change in its morpho-phonological shape (often identical to the 3rd person singular morphology) has been observed in a number of other languages in exactly the same context, viz., subject A'dependencies. The question is thus whether the factors and explanations proposed for these languages can be transferred to Awing. In section 2.1 we argue that IS- and anti-agreement-based approaches cannot be applied to Awing SM-drop. We provide evidence in section 2.2 that it is the referentiality of the subject that is the decisive factor.

2.1 The influence of information structure and $\mathrm{A}^{\prime}$-status. The absence of, or change in argument encoding morphology in constructions such as questions also occurs in a number of Bantu languages. For some of them, in particular those with SM-drop, it has been argued that the effect is related to information structure: The SM is an anti-focus marker, i.e., it can only double topical subjects, but not focused ones (see among others Zerbian 2006; Sabel and Zeller 2006; Zeller 2008; and van der Wal 2009; Halpert 2012 for a critique). ${ }^{5}$ Since questions words are considered to be inherently focused (Horvath 1986; Rochemont 1986; Tuller 1986; Sabel 2000; Haida 2007), the absence of the SM in subject questions follows. The effect of focus on subject marking is illustrated in (5) with data from Zulu: Focused subjects (cf. (5-a-i), accompanied by the focus-sensitive particle 'only') and wh-subjects (cf. (5-b)) cannot be doubled by the SM, whether they occur in their vPinternal (postverbal) base position or in the derived (preverbal) position SpecT. The only way to express the content is by using default agreement on the verb (and leaving the focused subject inside the focus domain vP), see (5-a-ii) and (5-c). ${ }^{6}$

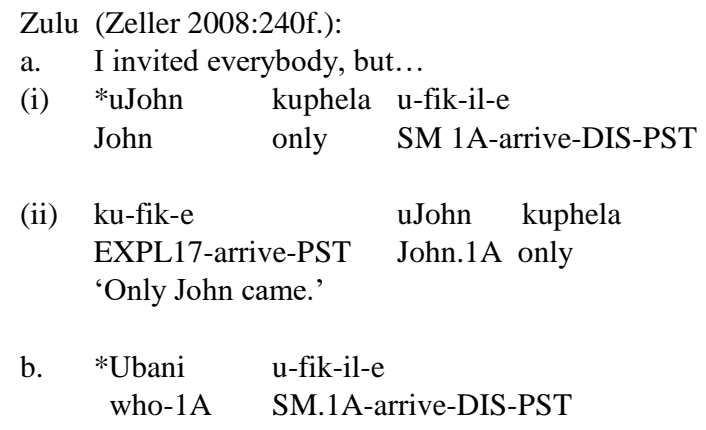

\footnotetext{
${ }^{5}$ Information structure has also been identified as a factor that conditions the presence/absence of object markers (OM) in several Bantu languages (see, e.g., Mursell 2018 on Swahili and Creissels 2004 on Tswana) but also outside of Bantu (see, e.g., the contributions in Dalrymple and Nikolaeva 2011)

${ }^{6}$ In Zulu and other Bantu languages, the SM only occurs when the subject moves out of the vP. When it stays inside the vP, it is focused (because the vP is the focus domain), and hence it cannot be doubled by the SM, see among others Zeller (2008) on Zulu. Similar observations have been made for clitic doubling in Romance languages, where clitics cannot double focused arguments, see among others Brandi and Cordin (1989); Manzini and Savoia (2002); Belletti (2001); Samek-Lodovici (2002); Anagnostopoulou (2006); Kallulli (2000).
} 
$\begin{array}{lll}\text { c. } & \text { ku-fik-e } & \text { bani } \\ & \text { EXPL17-arrivePST } & \text { who } \\ & \text { 'Who arrived?' } & \end{array}$

The question is whether SM-drop in Awing, a Grassfields Bantu language, can be analysed along the same lines as SM-drop in (some of) the closely related Bantu languages. An obvious difference to, e.g., Zulu is that Awing does not have the equivalent of default agreement, viz., a default SM; instead, the SM is completely absent in Awing where we see default agreement in Zulu. Apart from this morphological difference, the data set from Awing in (6) clearly shows that information structure, viz., the topic vs. focus status of the subject, is not the decisive factor for SMdrop in Awing: Subjects that are new-information foci (answer to a subject question, see (6-a)), accompanied by a focus-sensitive particle (see (6-b)) or contrastive foci (see (6-c)) can all occupy the derived (preverbal) subject position SpecT and still co-occur with the SM.

(6) a. Who cooked the food?

$\begin{array}{llll}\text { Alombah } & \text { (a) } & \text { nə } & \text { n-naynə məzíə } \\ \text { Alombah } & \text { SM } & \text { PST } & \text { N-cook food }\end{array}$

'Alombah cooked the food.'

b. tsó’ə Alombah (a) nə n-naynə məzíə

only Alombah SM PST N-cook food

'Only Alombah cooked the food.'

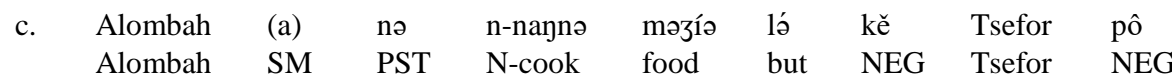

'Alombah cooked the food, not Tsefor.'

Thus, being in focus is not a sufficient condition for subjects to resist doubling. The absence of the SM with wh-subjects must have a different source in Awing. ${ }^{7}$

A second prominent approach to SM-drop in Bantu is to consider it an instance of the antiagreement effect (AAE), also attested in a number of Bantu languages (Schneider-Zioga 2000; 2007; Cheng 2006; Diercks 2010). According to the standard description of this phenomenon that goes back to Ouhalla (1993), the AAE describes the partial or complete loss of argument encoding morphology on the finite verb when the subject undergoes $\mathrm{A}^{\prime}$-movement (wh-movement, focus movement, relativization). This is illustrated for Tarifit Berber wh-movement in (7): In a declarative sentence the subject triggers agreement on the verb (see (7-a)), but when it is questioned, the verb must occur in a default (viz., invariable, non-agreeing) form (a participle form containing 3sg agreement) in Tarifit Berber, compare (7-b-c).

(7) Anti-agreement in Tarifit Berber under wh-movement (Ouhalla 1993: 479f., 487):

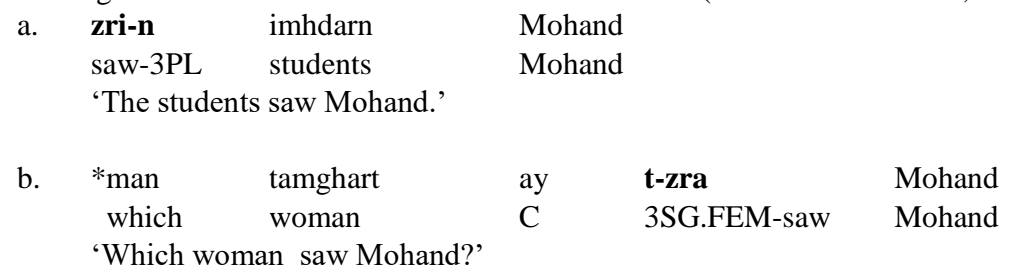

\footnotetext{
${ }^{7}$ In fact, the information structure status of the subject (viz., being in focus or being a topic) is also not the whole story for the aforementioned Bantu languages. As Halpert (2012) shows for Zulu, subjects that are new information foci can occur preverbally and are doubled by the SM, unlike the focused subjects in (5).
} 


$\begin{array}{lllll}\text { c. man } & \text { tamghart } & \text { ay } & \text { yzrin } & \text { Mohand } \\ \text { which } & \text { woman } & \text { C } & \text { see.PRTC } & \text { Mohand }\end{array}$

The Awing example in (4-b), in which the SM must be absent, may seems to fit this description: The subject is questioned and question formation often involves wh-movement of the subject to the left edge of the clause. The only difference to Berber would be that SM-drop results in the complete absence of any doubling/agreement morphology on the verb rather than the occurrence of default morphology. Crucially, for Ouhalla (1993) and other researchers after him the AAE is ultimately caused by $\mathrm{A}^{\prime}$-movement of the subject. ${ }^{8}$ More recent research on the AAE has argued that movement is not a necessary condition for the AAE, since there are also instances of the effect with in-situ arguments (focus/wh-in-situ), see Baker (2008a); Baier and Yuan (2017); Baier (2018). Based on this observation, Baier (2018) proposes an alternative, movement-independent analysis of the AAE. For him, the effect is purely morphological and triggered by A'-features on (instead of A'-movement of) the subject. More concretely, Baier assumes that the AAE is results from a post-syntactic impoverishment rule. For subjects and subject marking, this works as follows: The functional head $\mathrm{T}$ that triggers agreement with the subject does not only copy back the phifeatures of this argument but, if present, also the $\mathrm{A}^{\prime}$-feature(s) that the subject bears (viz., [WH] on a wh-subject, [FOC] on a focused subject, [REL] on a relativized subject, and [TOP] on a topical subject). In the post-syntactic morphological component, before vocabulary insertion, some or all phi-features on the agreeing head $\mathrm{T}$ are then deleted in the presence of $\mathrm{A}^{\prime}$-features on the same head. The deletion operation thus bleeds the insertion of the corresponding phi-exponents and hence leads to the complete absence of agreement morphology or to the insertion of a less specific (default-like) exponent, giving rise to the AAE. Transferring this analysis to Awing SM-drop, the impoverishment rule for a sentence like (4-b) with a wh-pronoun as the subject would look as follows:

$$
\varphi \rightarrow \varnothing /[\ldots, \mathrm{T}, \mathrm{WH}]
$$

All phi-features on $\mathrm{T}$ are deleted when $\mathrm{T}$ also bears a [WH]-feature, i.e., when the subject is a question word. Can we apply one of the prominent AAE-analyses, viz., an A'-movementinduced vs. an A'-features-induced approach, to SM-drop in Awing? As for A'-movement approaches, the answer is no. Awing does not seem to have wh- or focus movement to the left periphery of the clause at all. For subjects this is hard to show as their movement would be stringvacuous in an SVO language. But consider the object question in (9) (and the same holds for objects focus):

Wh-in-situ or clefting:

\footnotetext{
${ }^{8}$ The details are irrelevant for what follows, but we mention two prominent types of approaches here for the sake of concreteness: According to Ouhalla's (1993) A'-binding approach, subject movement creates an empty element in SpecT that is disallowed in this position because it is A'-bound by the moved operator in SpecC, which induces a Principle violation. The repair strategy is to avoid licensing of this empty element in SpecT, by deleting rich agreement. According to anti-locality approaches to the AAE, the movement step from the canonical subject position SpecT in declarative sentences to the A-landing site (viz., SpecC) in the left periphery of the clause is considered to be too short and thus to violate an anti-locality requirement on movement dependencies (Brandi and Cordin 1989; Campos 1997; Cheng 2006; Rizzi and Shlonsky 2007; Schneider-Zioga 2007; Diercks 2010; Erlewine 2016). One solution is for the subject to skip SpecT when it undergoes A'-movement and moves directly from Specv to SpecC. But since movement to SpecT is what triggers agreement, agreement is absent in the converging derivation. For discussion of more approaches to the AAE, see Baier (2018).
} 
a. Alombah (a) nə n-náynə ká əzooná Alombah SM PST N-cook what yesterday 'What did Alombah cook yesterday?'

wh-in-situ

$\begin{array}{ccccc}\text { b. *ká Alombah } & \text { (a) } & \text { nə } & \text { n-nánnə } & \text { əzooná } \\ \text { what Alombah } & \text { SM } & \text { PST } & \text { N-cook } & \text { yesterday } \\ \text { 'What did Alombah cook yesterday?' } & \end{array}$

'What did Alombah cook yesterday?' wh-ex-situ

$\begin{array}{lllllllll}\text { c. lá ká } & \text { [CP OP } & \text { pa'’a } & \text { Alombah } & \text { (a) } & \text { nə } & \text { n-náynə } & \text { əzooná ] } \\ \text { LE what } & & \text { that } & \text { Alombah } & \text { SM } & \text { PST } & \text { N-cook } & \text { yesterday }\end{array}$

'What did Alombah cook yesterday?'

cleft

In general, Awing has two strategies to focus or question arguments: (i) the XP stays insitu (see (9-a)), or (ii) the XP is clefted and we get a biclausal structure where the foucsed XP is followed by a relative clause, see $(9-\mathrm{c})(\mathrm{OP}=$ the relative operator). What is impossible is to front a wh-element to any of the edges of the clause, see (9-b) for the attempt to do leftward wh-movement (rightward displacement is also ungrammatical). There is also no long-distance A'-movement. Long dependencies necessarily involve clefts in Awing (see Fominyam in prep.). Given these facts, we do not have any reason to believe that there is focus/wh-movement in Awing. Thus, SM-drop as in subject questions (see (4-b)) cannot be triggered by A'-movement of the subject. As a consequence, neither of the classic movement-based AAE-approaches can be applied to Awing SM-drop. What remains is Baier's analysis that makes reference to A'-features on the subject and is independent of whether this argument undergoes $\mathrm{A}^{\prime}$-movement or not. The analysis has been outlined above with the impoverishment rule in (8). The idea would be that the SM expresses agreement with the subject on the head T; but prior to vocabulary insertion these phi-features are deleted in the presence of the [WH]-feature also copied from the (question word) subject. However, this approach fails as well given the data in (10). The examples illustrate that not all wh-subjects behave alike with respect to SM-drop: While a wh-pronoun as the subject of the sentence cannot be doubled by the SM, a whphrase (which-phrase) can. In the latter case the SM is optional, just as it is in declarative sentences.

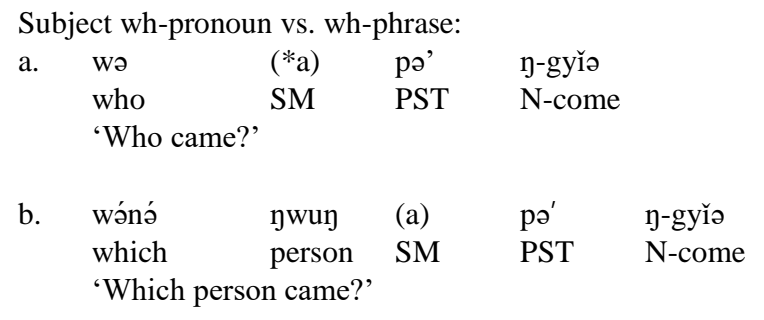

Crucially, however, both subjects bear a [WH]-feature. Baier's approach would thus predict that the SM is either absent in both sentences (when the rule in (8) is active in the language), or that it can be present in both contexts (when the rule in (8) is not active). A split between (11-a) and (11-b) is unexpected though, unless a more fine-grained $\mathrm{A}^{\prime}$-feature system is adopted. But even if this is done, the question remains what the relevant difference between these two contexts is that the feature-system should reflect. The same argument can be made based on the examples with subject focus in (6): Given that all of these subjects as well the wh-subject in (4-b) could be said to bear the feature [FOC] (since wh-elements are inherently focused), we could model the absence of the SM in this wider set of contexts by replacing [WH] in the impoverishment rule in (8) with [FOC]. However, SM-drop is not obligatory with all focused subjects, e.g., not with which-phrases. Such a split is unexpected in Baier's approach (given the set of features he proposes). 
We can thus conclude that none of the two prominent analyses for argument marker drop/reduction in Bantu (and other) languages can be applied to Awing SM-drop. Neither the information structure status nor the presence of A'-features (with or without A'-movement) correctly picks out the class of contexts in which SM-drop occurs. This does not mean that the aforementioned approaches to argument marker drop are wrong in general, they are just not suitable for Awing SMdrop.

2.2 On the role of referentiality. The question is what governs SM-drop in Awing if it is not information structure, $\mathrm{A}^{\prime}$-movement or $\mathrm{A}^{\prime}$-features. Considering more data points, we will see that SM-drop does not only occur in (certain) subject questions, but also in a number of other contexts that are not related to $\mathrm{A}^{\prime}$-features at all. We will show that the crucial factor that unifies these contexts is the referentiality of the subject: Only fully referential subjects can be doubled by the SM, while less and non-referential ones must not be doubled, resulting in SM-drop. We are aware of the fact that referentiality is a somewhat vague notion that has been defined in various ways (see Chen 2009; Aguilar-Guevara et al. 2014 for recent overviews) and there are both semantic and pragmatic aspects of this concept. But it is undisputed that referentiality plays an important role in grammar, not just in semantics-pragmatics (see among others Karttunen 1968; Partee 1970; Lyons 1977; Fodor and Sag 1982; Heim 1982) but also in morphology (Baker 1996; Baker and Kramer 2018) and in syntax (see Pesetsky 1987; Cinque 1990; Rizzi 1990; Manzini 1992; Chung 1994). Following Chen (2009), instead of working with a specific (and contested) definition of the term, we consider it more fruitful to simply consider the contexts that have been discussed in the literature under the label referentiality, and to show that they indeed have an effect on subject marking in Awing. Thus, in what follows, we use the term "referentiality" as a short-hand approximation to describe these contexts. ${ }^{9}$

In the aforementioned literature, nominal expressions with reduced referentiality are the following: non-D-linked, generic, non-specific and idiomatic nominal expressions, inherently nonreferential quantifiers, and non-ostensive contexts. We will illustrate below that in all of these contexts subjects cannot be doubled by the SM in Awing. Let us start with the wh-examples in (10), repeated in (11). We saw that a wh-feature on the subject does not automatically trigger SM-drop in Awing: While a wh-pronoun obligatorily causes the loss of the SM, a which-phrase subject does not (SM-drop is optional here):
D-linking:
a. wə
(*a) pə' $\quad$-gy̌̃
who SM PST N-come
'Who came?'
b. wáná ywuy (a) pə’ y-gy̌̌
which person SM PST N-come
'Which person came?'
D-linked

It is well-known that there is a difference in referentiality between wh-pronouns and whichphrases, referred to as D(iscourse)-linking in Pesetsky (1987): A which-phrase asks for a referent from a presupposed, contextually salient set of referents, similarly to partitive case, i.e., which one

\footnotetext{
${ }^{9}$ Considering the contexts that we will discuss below, specificity might be a candidate for an alternative term that influences subject marking in Awing. Radek Šimík (p.c.) suggests that what we call less referential contexts are better characterized as a kind of epistemic identifiability.
} 
of those previously mentioned referents has property X? Put differently, the person who asks a which-question has a set of potential, plausible answers in mind. A wh-pronoun, on the other hand, is not necessarily discourse-linked in this way. In that sense which-phrases are said to be more referential than wh-pronouns. Subject marking in Awing is apparently sensitive to the D-lining status of a wh-subject (as are syntactic processes in other languages, e.g., superiority and intervention effects in English, see Pesetsky 2000).

Another usage in which nominal expressions are not (or at least less) referential compared to, e.g., proper names or personal pronouns is generic uses, see (12). (12-a) describes a general property of goats, it specifies a characteristic of the class of goats, not of a particular goat. To express this generic meaning, the SM in Awing must be absent. If the SM is added to this example, as in (12-b), the generic reading is lost. (12-b) can only have a reading in which we attribute the expressed property (that of having four legs) to a specific goat in the discourse, but we do not express that it is a property shared by all goats.

Genericity:
a. mbénə
goat
tu'g mo-koolə
mən nə-kwa

"A goat (in general) has four legs. / Goats have four legs."

*'A specific goat has four legs.'

generic
b. mbénə ə tu'g mə-koolə mən nə-kwa
goat SM have PL-leg L PL-four
"A specific goat has four legs."
*'A goat (in general) has four legs.'

non-generic

More generally, non-specific indefinite uses of nominal expressions have also been subsumed under less referential contexts in the literature: If an indefinite nominal expression refers to a specific entity, it is more referential than a non-specific nominal. In fact, this difference has consequences for subject marking in Awing: If a bare subject noun is to be construed as a specific indefinite, the SM must be used, see (13-a) (and also (12-b)). If the SM is dropped in this sentence, the specific reading is lost, see (13-b); the bare noun subject can then only receive a non-specific indefinite reading (some unknown woman).

$$
\begin{aligned}
& \text { Specificity: }
\end{aligned}
$$

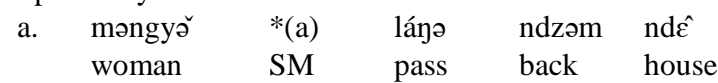

$$
\begin{aligned}
& \text { 'A certain woman passes behind the house.' }
\end{aligned}
$$

specific indefinite

non-spec. indefinite

The same effect of specificity on subject marking in Awing is illustrated in the sentences

\begin{tabular}{|c|c|c|c|c|c|}
\hline ntsó’ə-ghonə & $(* a)$ & nə-ndá' & n-fíto & mə & நgə \\
\hline cure-illness & SM & PST & $\mathrm{N}$-tell & me & that \\
\hline mə-kっ'-nə & mən & 1ว̀-ətǐa & & & \\
\hline INF-eat-INF & butt & link-tree & & & \\
\hline
\end{tabular}
in (14), with the bare noun matrix subject 'doctor': 
The sentence-internal context suggests that we are talking about some random doctor, not a specific doctor. The identity of the doctor is in fact irrelevant for the core information expressed, viz., that eating lots of fruits is healthy. The matrix clause just adds the information that this statement has been approved by an expert, viz., a doctor, to lend credibility to it. The concrete identity of the doctor does not matter for this purpose. Hence, 'doctor' is interpreted here as a nonspecific indefinite. And in fact, the SM must be absent in this sentence in Awing. Adding the SM necessarily leads to a specific indefinite reading of 'doctor'.

A fourth non-referential usage of nominal expressions can be found in so-called nonostensive contexts, see (15) for an example:

non-ostensive uses:

Context: A detective is called to a crime scene. A person named Alombah has been found dead, probably murdered. After arriving at the crime scene and briefly looking at the badly injured dead body, the detective says:

ngwitə Alombah (*a) lán tsantə

murderer Alombah SM very strong

'The murderer of Alombah is very strong.'

(Paraphrase: Whoever the murderer is, s/he must be very strong.)

At the point at which the detective utters this sentence, s/he does yet know who the murderer is, since s/he has just arrived at the crime scene and only had a brief look at the murdered person. Thus, the identity of the murderer is unknown; it is only the condition of the dead body that leads to the detective's statement that the murder - whoever s/he is - must be a strong person. In such a context in which the identity of the subject is unknown or irrelevant (even though the noun 'murderer' is a referential expression and could be used as such), the SM cannot be used in Awing. ${ }^{10}$

Next, we consider quantifiers in subject position. Quantifiers like 'somebody' and 'nobody' are inherently non-referential and we thus expect them to be incompatible with the SM in Awing when they function as the subject of the clause. (16) shows that this is in fact the case:

$$
\begin{aligned}
& \text { Non-referential Qs (not lexicalized in Awing): } \\
& \text { a. ywun-tsá }(* a) \text { nạ ndzǒ } \\
& \text { person-IND SM cook beans } \\
& \text { 'Someone has cooked beans.' } \\
& \begin{array}{lllllll}
\text { b. } & \text { ywun-tsá } & (* a) & \text { kě } & \text { ndzǒ } & \text { nay } & \text { pô } \\
& \text { person-IND } & \text { SM } & \text { NEG } & \text { beans } & \text { cook } & \text { NEG }
\end{array} \\
& \text { 'Nobody has cooked beans.' }
\end{aligned}
$$

Note first that Awing does not have lexicalized quantifiers like somebody or nobody; they are expressed with the help of the noun for 'person', ywun. As (16-a) shows, the word for 'person' can only be interpreted as 'somebody' when the SM is absent; adding the SM to this example will again lead to a specific indefinite interpretation, viz., that a specific person cooked beans. The same pattern holds for the expression of the negative version 'nobody': This meaning is expressed by the word for 'person' in subject position, sentential negation and, crucially, the obligatory absence of the SM, see (16-b). Parallel to (16a), using the SM in (16b) would be interpreted as 'a certain person did not cook beans'. Partitative quantifiers like 'few' or 'most' are also sometimes grouped under

\footnotetext{
${ }^{10}$ If the SM were present in (15), in a different context, this would mean that the speaker has someone in mind that s/he is suspecting. The use of the SM would already be identifying someone.
} 
non-referential expressions. They are more referential than expressions like 'somebody' in that they do refer to elements with a certain property, however, only to a non-specific subset (the exact number and identity of the referents remains unclear). They denote vague quantities. For this reason, partitative quantifiers are also expected to be incompatible with the SM in Awing given the influence of referentiality on subject marking exemplified above. And indeed, vague quantifiers $+\mathrm{N}$, viz., $n t a$ lo 'few' and $n d o$ 'about', in subject function cannot be doubled by the SM in Awing, see (17). ${ }^{11}$

Vague quantities:

$\begin{array}{llllll}\text { a. nta'lə } & \text { pónkə̂ } & \left({ }^{*} \text { po }\right) & \text { nə } & \text { y-ghenə⿱ } & \text { ajwarə } \\ \text { few } & \text { children } & \text { SM } & \text { PST } & \text { N-go } & \text { school }\end{array}$

'Few children went to school.'

b. ndo pónkê pen teeló (*po) nə

about children L three SM PST N-go school

'About three children went to school.'

Let us also mention weather expressions in this context. Unlike in English, the statement 'It is raining.' is not expressed with a weather verb and an expletive subject in Awing. Rather, one literally says 'Rain is falling.' with a bare nominal as the subject. Interestingly, the SM is prohibited in such a construction, see (18a).

\begin{tabular}{|c|c|c|c|c|c|}
\hline \multicolumn{6}{|c|}{ Weather expressions: } \\
\hline \multirow[t]{3}{*}{ a. } & mbəy & $(* \partial)$ & tá & n-dó & \\
\hline & rain & SM & PROG & $\mathrm{N}$-fall & \\
\hline & 'It is $r$ & & & & \\
\hline \multirow[t]{2}{*}{ b. } & nta'lo & mbəy & (ə) & nə & n-dó \\
\hline & drop & rain & SM & PST & $\mathrm{N}$-fall \\
\hline
\end{tabular}

However, the amount of rain can be quantified by specifying a certain amount that fell. In such cases, the SM will be optional (18b).

It is not surprising that the SM is prohibited in (18a), given the hypothesis that the SM can double only referential (i.e., non-generic, specific) expressions: (18a) only expresses the fact that rain is falling, but not how much rain exactly, nor does it refer to specific rain drops. Rather, we talk about an unknown amount of rain. In this sense the subject noun qualifies as not fully referential and SM-drop is expected. ${ }^{12}$

\footnotetext{
${ }^{11}$ The occurrence of the SM with exact (rather than vague) quantities cannot be tested in Awing. There are no lexical items in the language that encode meanings such as 'exactly'. To express this, a construction has to be used in which the subject occurs in the post-verbal position and is exhaustively focused. However, in this construction subject marking is generally impossible, regardless of the referentiality (or other properties) of the subject. This post-verbal subject construction and the reason for the absence of the SM in this context is discussed in section 4.1. Also, a quantifier like 'both' could constitute a good test but unfortunately Awing does not have a lexical form expressing this. One would have to say something like 'two of them', with the use of a prepositional phrase in the postverbal position.

${ }^{12}$ An anonymous reviewer suggests that this may imply that mass nouns in Awing would generally occur without the SM. This is not the case: the examples in (i) show that not all mass nouns behave like "rain" with respect to subject marking. However, example (ii) with "dust" cannot take the SM, analogous to "rain".

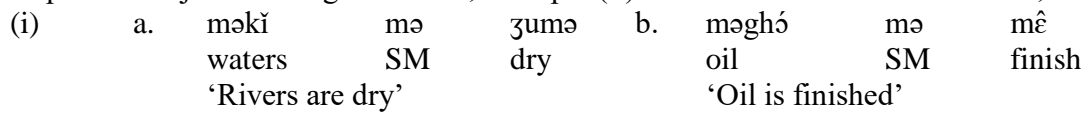


The literature also reports on a difference between distributive universal quantifiers (DUQ) like 'each' and universal quantifiers (UQ) like 'all' in languages with referentiality-based restrictions on argument marking morphology (see among others Cinque 1990; Baker 1996; Safir 2017; Baker and Kramer 2018): DUQs can or must be doubled by argument encoding morphology, while UQs cannot be doubled. Note that Awing does not have a lexical distinction between the two types of universal quantifiers, unlike English; it uses the same word tsam different meanings are expressed in two ways: First, DUQs combine with a singular noun and UQs combine with a plural noun (compare English each boy vs. all the boys). Second, and most relevant for present purposes, the SM must be present in the DUQ-use (tsəmə $+\mathrm{N}_{s g}$ ), while it is optional in the UQ-use (tsama $+\mathrm{N}_{p l}$ ), see (19).

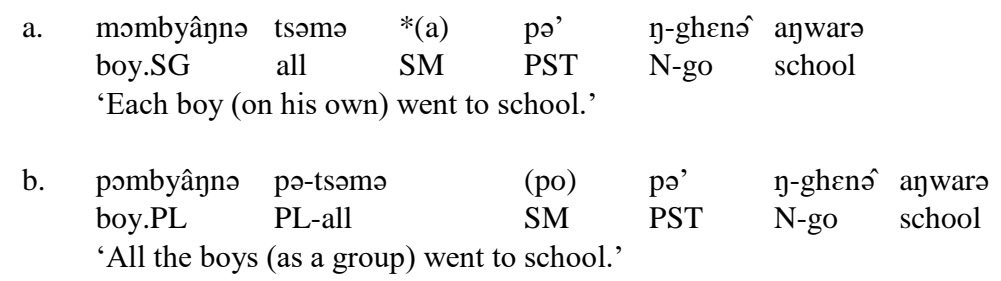

Again, Awing subject marking behaves as expected when the occurrence of the SM is related to referentiality. Given the previous literature on the topic, one might expect the SM in (19b) to be impossible, but it can optionally be present in Awing. What is important, though, is that there is a contrast in SM marking between (19a) and (19b).

As a final piece of evidence for the role of referentiality in Awing subject marking we consider idioms, in particular idiomatic phrases (vs. idiomatically combining expressions, see among others Nunberg et al. 1994; van Craenenbroeck et al. 2016). Nouns that are part of idiomatic phrases do not refer (Fellbaum 1993; Nunberg et al. 1994; Grégoire 2009), since the whole expression has a non-literal meaning. This is clear from the fact that such nouns cannot be taken up by a co-referring pronoun (underlined), as illustrated for two English idiomatic phrases in (20).

English idiomatic phrases van Craenenbroeck et al. (2016: 15)

a. \#After John kicked the bucket, his wife got rid of it.

b. \#I'm sure he'll bite the dust if he keeps on eating it.

Fortunately, Awing has idiomatic phrases that contain a noun in subject position, see the two examples in (21) and (22). Crucially, the SM cannot appear in such idioms since the subject is non-referential (and this subject can also not be taken up by an anaphoric pronoun in a following sentence). The SM can be added to these sentences, but then the idiomatic reading is lost and the subject noun has its literal meaning, i.e., it becomes referential, see the b-examples.

Idioms including the subject:
a. apô
$\begin{array}{ll}\text { tá } & \text { libê } \\ \text { PROG } & \text { hang }\end{array}$
$\begin{array}{ll}\text { apeemə } & \text { kê } \\ \text { bag } & \text { NEG }\end{array}$
éwá
chí
pô
$\boldsymbol{\checkmark}$ 'All work is noble.'
'AROG
*'A hand that cannot hang a bag does not exist.'
(idiomatic)
(literal)

(ii) akəpógló $(* ə) \quad$ kəpkə ygəsáyə́ afoonə
Dust SM cover maize farm
'Dust has covered the maize in the farm'

We leave it for future research to determine what governs the choice of the SM with mass nouns in Awing. 


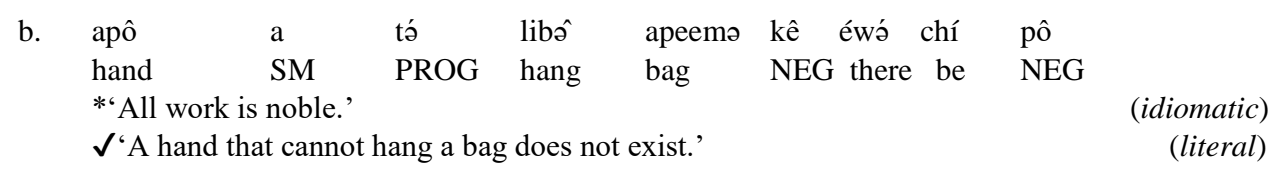

Idioms including the subject:

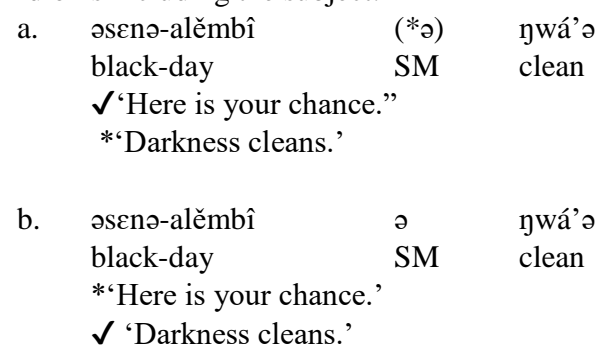

(idiomatic)

(literal)

To summarize, we have found that the occurrence of the SM in Awing is conditioned by the referentiality of the nominal subject. Fully referential expressions can (optionally) be doubled by the SM, while less/weak or even non-referential ones must not co-occur with the SM. Less referential uses of subjects (according to the referentiality literature) include non-D-linked, generic, non-specific, and non-ostensive uses, quantifiers (inherently non-referential ones like 'somebody' and vague quantities like 'few') and subjects as parts of idiomatic phrases. In all of these contexts the SM is prohibited in Awing. Moreover, we have not found any evidence that the properties of other arguments interact with subject marking. For example, it is completely irrelevant whether, e.g., the direct object is referential or not; it can be a wh-pronoun, but as long as the subject is referential, the SM can occur, see (23).

$\begin{array}{llll}\text { Ngwe (a) pe' } & \text { n-dzunə ká } \\ \text { Ngwe SM } & \text { PST } & \text { N-buy } & \text { what } \\ \text { 'What did Ngwe buy?' } & & \end{array}$

(Fominyam in prep.: ch.6)

Likewise, other non-argumental elements and their properties which have been claimed to influence argument encoding in other languages, such as the transitivity of the predicate or the TAMvalues expressed, also have no impact on the presence/absence of the SM in Awing.

\section{Analysis}

In this section we propose a formalization of the observation that the SM in Awing can double only referential nouns. To this end, we will discuss the nature of the SM (agreement vs. pronoun), the relation between the SM and the associated subject NP as well as the optionality of the SM with referential subjects. In a nutshell, we propose that the SM is a pronominal clitic that functions as the thematic argument of the verb when it surfaces. The associated subject NP is then just an adjunct base-generated at the left edge of the clause. Cross-linguistically, the nouns that cannot be doubled by the SM in Awing (viz., the less referential ones) are known not to be tolerated in such a leftdislocated position (see among others Alexiadou and Anagnostopoulou 1998; Rizzi 1986; 1990; Cinque 1990; Baker 1996; 2003). Hence, the SM + adjoined NP-structure is impossible with a nonreferential subject NP. The only remaining option in such contexts is not to use the SM and to merge the (less/non-referential) subject NP as the thematic argument of the verb. This option is of course also available for referential subjects, which leads to optionality in the use of the SM with referential subjects. 
3.1 On the properties of the SM. The first question we want to address is the nature of the SM in Awing. Is it an agreement morpheme that expresses phi-feature agreement between the subject and the verb, or is it a pronominal element (a pronominal clitic) that doubles the associated subject NP? We will consider several tests from the literature to shed light on the issue (see Jelinek 1984; Bresnan and Mchombo 1987; Baker 1996; Alexiadou and Anagnostopoulou 1998; Baker 2003; Preminger 2009; Kramer 2014; Baker and Kramer 2018 and the references cited there). We will conclude that it is in fact a pronominal element and not an agreement morpheme.

Note first that the SM can function as a subject pronoun: When the referential NP subject is dropped, the SM is obligatory and receives a pronominal interpretation, see (24-a-b) (and Fominyam and Šimík 2017: 1034 for the observation and more examples).
a. a nə n-nánnə məzíə SM PST N-cook food 'S/he cooked the food.'
b. *nə n-nánnə məzía
PST N-cook food
'S/he cooked the food.'
c. *a na n-nánnə məzí
s/he SM PST N-cook food
'S/he cooked the food.'

If the SM were an agreement marker, we would expect it to be able to double all kinds of subjects, including personal pronoun subjects in a sentence like ' $\mathrm{S} /$ he cooked food'. For pronominal subjects, this is not possible, however: In (24-c), we cannot have the $a$-morpheme twice (once as the personal pronoun and once as a putative agreement marker), a fact to which we will return in section 4.2. If one wanted to save the agreement hypothesis one would have to say that the subject in (24a) is a pronoun and that Awing has obligatory pro-drop; however, the finding is suggestive and we will provide more evidence for the pronoun analysis below.

Second, with referential subject NPs, the SM is optional. Pure, bona-fide agreement is, however, obligatory and independent of the referential status of the agreement controller (see among others Corbett 2006; Kramer 2014) and has no semantic effects (like specificity of the referent). Take, for example, subject-verb-agreement in English: The verb agrees with a 3 sg subject regardless of its referentiality (referential NP, non-referential quantifier, generic reading): 'The man is intelligent.'/'Nobody is intelligent.'/'A dog has four legs'.

Third, pronominal clitics only vary according to the inherent (phi-) features of the doubled noun, but their morpho-phonological form is not influenced by verbal features in the clause such as TAM-values. Agreement, on the other hand, can exhibit allomorphy based on such verbal categories (Nevins 2007; Kramer 2014). The paradigm of SM forms in (2) shows that the SM in Awing in fact only co-varies with inherent properties of the subject noun (animacy, number); hence, it behaves more like a pronominal clitic than agreement.

Fourth, Preminger (2009) argues that a failed agreement relation results in default agreement morphology on the surface, while failed clitic-doubling (of a pronominal element) simply results in the absence of the marker, without any other additional default morpheme. Before we consider the Awing data against this background, let us ask what would probably be the default marker in Awing (if the SMs were agreement markers). Cross-linguistically, default form are 3sg markers, more precisely the masculine or neuter ones if the languages expones gender. Awing does 
not have gender but animacy. It is not so clear whether the human or the non-human form would be the default then, but in any case it should be either $a$ (3sg human) or á ( $3 \mathrm{sg}$ nonhuman), compare (2). As we have seen in the examples in section 2.2, when the SM is blocked because the subject is to receive a non-referential reading, no other default-like marker replaces the SM in this context: With a 3sg non-human subject (see (12)) we do not get a switch from the usually expected $a$ to $a$ (the potential default), nor do we get $\partial$ as a potential default with $a 3 \mathrm{sg}$ human subject that is nonreferential (e.g., non-specific indefinite, see (13-b)). Instead, what we see is that the SM is simply absent with non-referential subjects. According to Preminger's test this suggests that the SM is a doubled clitic in Awing and not an agreement marker.

Fifth, the same morphemes that occur as the SM in declarative sentences are used as resumptive pronouns. So far, we have only discussed examples in which the SM is either optional (with referential subjects) or obligatorily absent (with non-referential subjects). However, there are also contexts in which it is obligatory. These include subject relative clauses and subject topics (both in short and long-distance dependencies), see (25):

a. Context: Alombah, Tsefor and Aghetse did not go to the market with the rest of the family in the morning but rather stayed at home. When the family returns around noon, they ask what everyone has been doing in the morning. Aghestse reports the following:

$\begin{array}{lllll}\text { Alombah, } & *(a) & \text { nə } & \text { n-nánnə } & \text { məzíə } \\ \text { Alombah } & \text { SM } & \text { PST } & \text { N-cood } & \text { food }\end{array}$

'As for Alombah, he cooked the food.'

subject topic
b. Alombah
(a) jí
ywún
pá'a
Alombah
SM
know
man that
*(a)
nə
n-nánnə məzíə
$\mathrm{N}$-cook food
'The woman knows the man who cooked the food.'
relativized subject

In the literature on information structural categories, relativized XPs have been classified as being topic-like (rather than foci, see Bresnan and Mchombo 1987; Rizzi 1997; Douglas 2017), in this sense it is not surprising that the two contexts in (25) show the same behaviour with respect to obligatory subject marking. If the SM were an agreement marker, it would be mysterious why it suddenly becomes obligatory in these contexts. The facts are less surprising if the SM is a pronominal element that functions as a resumptive pronoun: Cross-linguistically, and also in NigerCongo languages, it is common for topicalization and for relativization - especially of subjects (see Comrie 1989 and Salzmann 2017:ch. 3.2.2 for overviews) - to require resumption. ${ }^{13}$

\footnotetext{
${ }^{13}$ Note that the SM in subject relatives is obligatory regardless of the referentiality of the head noun. Thus, even in cases where the SM is not obligatory in the corresponding declarative, it will be when the subject is the head noun of a relative clause, see e.g., the example in (iii) with a UQ subject (which does not necessitate the SM in a declarative, see (19b)), and example (iv) with the head noun "person" and sentential negation in the relative clause, which can have the "nobody" interpretation even though the SM is present (compare (16b)).

(iii) pəmbyânnə pə-tsəmə pá'a *(po) pə’ y-ghénô ajwarə (po) boy.PL PL-all that SM PST N-go school SM nə n-dounə ykənə-anwa'lə

PST N-buy stick-book

'All the boys that went to school bought pens.'

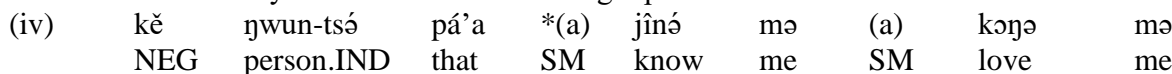

'Nobody that knows me loves me'

It has sometimes been claimed that matrix subjects cannot be resumed, while embedded subjects are associated with a resumptive in a number of languages, e.g., in Hebrew and Irish. This constraint is known as the Highest Subject Restriction (McCloskey 1990). However, this restriction is not universal, as a number of languages that
} 
Sixth, a subject that cannot be doubled by the SM in a sentence S1 can also not be taken up by a pronoun in a follow-up sentence S2 (such that the subject in S2 refers back to the subject in S1). Take, for example, the interpretation of the noun for 'person' in (16-b). As noted, the nonreferential interpretation 'nobody' is only obtained when the SM is omitted. Hence, in a follow-up sentence, no pronoun can be used to refer back to the non-referential subject in (16-b); see (26-a) below. However, the specific indefinite interpretation ('a certain person did not do X'), which is said to be available when the SM is used can be followed by the SM, as in (26-b).

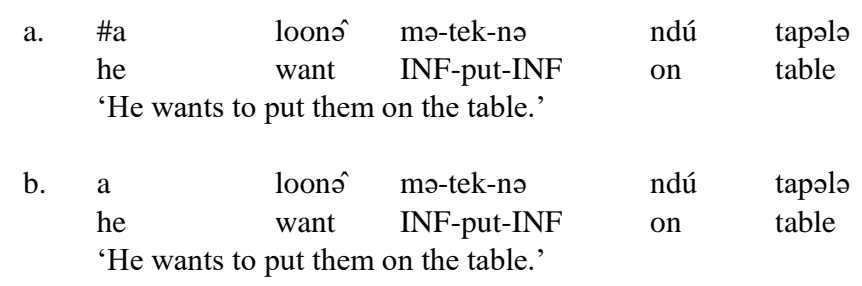

The string in (26-a) as such is grammatical; what leads to its degradedness is that the subject pronoun is intended to refer back to the subject in (16-b). Thus, the SM behaves like an anaphoric pronoun in a different sentence. This parallel is expected if the SM is a pronoun.

Finally, let us consider a cross-linguistic argument for the pronominal status of the SM in Awing. Baker and Kramer (2018) recently revived the discussion of how to determine whether verbal markers that double arguments (subjects or objects) are (pronominal) clitics or agreement morphemes. The abstract pattern they investigate on the basis of object marking in Amharic - but which is also attested in numerous other languages (including a number of Bantu languages, see e.g., Bresnan and Mchombo 1987 on Chichewa) - is illustrated in (27) ( $\mathrm{S}=$ subject, $\mathrm{O}=$ object, $\mathrm{V}=\mathrm{verb}$ ). We added a random example as a rough translation to give an impression of the construction type in English; we used SVO order for the sake of illustration, but the linear order of the arguments is irrelevant for the discussion (it is in fact SOV in Baker \& Kramer's Amharic examples). First, it is possible for the object to occur without the object marker (OM) in the languages studied by Baker \& Kramer, see (27-a), but the OM can also double the object, see (27c); the OM is thus optional. Finally, the OM can also occur alone, without the object noun phrase, and then has a pronominal interpretation, see (27-b).
a. $\quad \mathrm{S}$ V O
b. S V-OM
c. S V-OM O
"John cooked the food."
"John cooked it."
"John cooked it the food."

Baker and Kramer (2018) point out that the problem with the analysis of the OM in languages with the distribution in (27) is that it looks like agreement in (27-c) (where it doubles the object NP), but like a pronoun (that itself functions as the object argument / replaces the object NP) in (27-b). The data set is thus ambiguous on the surface between a pronominal and an agreement analysis of the argument doubling marker. Baker and Kramer (2018) argue against previous technical solutions to this problem that try to provide either uniform agreement or uniform (pronominal) clitic-doubling accounts of all occurrences of the OM in (27). Instead, they argue on empirical grounds that a principled explanation of the pattern can be given when the OM is a doubled

also allow for matrix subject resumption have been found, see Klein (2016); Salzmann (2017) for recent overviews. Awing seems to belong to this latter group of languages and requires RPs for all relativized subjects. 
clitic that is interpreted as a pronoun at LF. Its distribution than falls out automatically from general (universal) properties/constraints of the grammar (cross-over phenomena, binding principles). A crucial observation that leads them to this analysis is the fact that in languages with the pattern in (27), the OM cannot (optionally) double all object NPs. Rather, doubling is only possible with referential objects; what Baker and Kramer (2018:1037) call informally "less than fully referential" nominals - including non-specific, generic, interrogative pronouns, and quantified nominals cannot co-occur with the OM. They conclude that if argument doubling in a given language is only possible with referential arguments, the doubling device must be pronominal and cannot be agreement morphology.

Crucially, Awing exhibits the same abstract distribution for doubling devices presented in (27) as the languages discussed in Baker and Kramer (2018). The only difference is that we see the effect for subject marking instead of object marking. The corresponding SM-pattern is illustrated in (28): The SM can optionally double the subject (see (28-c)), but it can also occur without the subject NP (see (28-b)). Furthermore, as we have argued in section 2.2, we find the same referentialitybased constraint on doubling that Baker and Kramer (2018) base their analysis on, viz., that only referential arguments can be doubled. Following their argumentation and also taking into account the other pieces of evidence provided in this section, we conclude that the SM in Awing is a pronominal clitic (more evidence for the clitic status will be provided in section 4.2). The same result, viz., that SMs are pronominal clitics, has been found in a number of other Bantu languages (see among others Bresnan and Mchombo 1987; Young 2005; Schneider-Zioga 2007). Coming back to the introduction, we can conclude that while information-structure based approaches and AAEapproaches (related to A'-movement or A'-features) cannot account for the distribution of the SM in Awing, the morpho-syntactic status of the SM (pronominal) provides a handle to understand the pattern.
a. $\quad \mathrm{S} V \mathrm{O}$
b. SM-V O
c. S SM-V O
"John cooked the food."
"He cooked the food."
"John he cooked the food."

3.2 The relation between the SM and the associated NP. Having established that the SM in Awing is a pronominal element, the question arises what its relation is to the associated subject NP when they co-occur in a sentence. There are two broad types of approaches in the literature on pronominal clitic doubling and dislocation constructions involving pronominal resumption (see Alexiadou 2017 for an overview and references): base-generation and movement approaches. In the former, the pronominal element is the thematic argument of the verb, while the associated NP is an adjunct that is base-generated at the left edge of the clause and binds the pronoun. Under movement approaches the associated NP moves to its left-peripheral position from within the vP; the pronoun is then either the spell-out of the trace/lower copy of the moved NP or, under Big-DP approaches, the pronoun and the associated NP start out as a single constituent of which only the NP part undergoes movement, while the pronoun is stranded. Movement dependencies can be diagnosed by connectivity effects, i.e., the associated NP behaves morpho-syntactically and semantically as if it were in its base position inside the vP. We will show now that the relation between the subject NP and the SM does not exhibit connectivity effects; we thus conclude that the associated NP is basegenerated in its surface position rather than moved from a lower vP-internal position. ${ }^{14}$

\footnotetext{
${ }^{14}$ Another common diagnostic for movement is island-sensitivity. However, we cannot apply this test in Awing: We argued that the SM is a pronominal element and acts as a resumptive, e.g., in relative clauses. It is
} 
We will investigate semantic connectivity effects in Awing in what follows. First, it is generally assumed that an idiomatic interpretation is only possible when the parts of the idioms are close together at LF, viz., in their base position (inside vP). If a subject NP that is part of an idiom and doubled by the SM were moved to its left-peripheral surface position from a vP-internal position, the idiomatic reading should still be available because the subject NP could be interpreted in (reconstructed to) this low position. However, as already shown in (21), the idiomatic reading is lost when the SM is present, it can only obtain without the SM. The second piece of evidence for the absence of connectivity effects comes from scope. A SM doubled subject NP always takes wide scope with respect to a scope-taking element such as negation, which is below the NPs' surface position but above its (potential) base position in Specv. Consider the examples in (29):
a. móo-mbyânno
child-man
$\begin{array}{ll}\text { a } & \text { kě } \\ \text { SM } & \text { NEG }\end{array}$
məzío
*'No boy cooks food.'
$\checkmark$ 'A certain boy does not cook food.'
b. móo-mbyâynə kě məzía nán
$\checkmark$ 'No boy cooks food.'
$\checkmark$ 'A certain boy does not cook food.' child-man NEG food cook NEG

náy

po $\leftarrow$

When the SM is present as in (29-a), the subject must take scope over negation, a low scope reading is out. If the SM is absent, however, we get ambiguity between a wide and a low scope reading with respect to negation; see (29-b). Recall also in this context that Awing does not have lexicalized negative quantifiers, but rather expresses this meaning by the noun for 'person' plus sentential negation, see (16-b) repeated in (30). Crucially, we get the 'nobody'-interpretation (wide scope of negation over 'person') only when the SM is absent. In fact, this example is ambiguous between wide and low scope of negation, in parallel to (29-b).

$$
\begin{array}{llllll}
\text { ywun-tsó } & (* a) & \text { kě } & \text { ndzǒ } & \text { nay } & \text { pô } \\
\text { person-IND } & \text { SM } & \text { NEG } & \text { beans } & \text { cook } & \text { NEG } \\
\text { 'Nobody cooks beans.' } & & &
\end{array}
$$

well known that resumptive pronouns can repair island violations (though there is cross-linguistic variation in this area, too), see Keenan and Comrie (1977); Maxwell (1979) for the initial observation, and Salzmann (2017) for an overview of the research on island repair by resumption. In fact, we see this effect in Awing: It is grammatical to relativize the subject from a complex NP island, see (v-b) based on (v-a). Even though (v-b) is a question, recall that long- distance dependencies in Awing always have to involve a cleft of the type $I t$ is $X$ that ... with an embedded relative clause; thus, the long island-spanning dependency in ( $\mathrm{v}-\mathrm{b})$ is an instance of relativization:

$\begin{array}{llllllll}\text { (v) a. } & \text { Tsefor } & \text { (a) } & \text { pe’ n-dzənə } & \text { ywún } & \text { pá'a Aghetse (a) } & \text { kəynə } \\ & \text { Tsefor } & \text { SM } & \text { PST N-see } & \text { man } & \text { that Aghetse SM } & \text { love }\end{array}$

'Tsefor saw the man that Aghetse loves.'

$\begin{array}{lllllllllll}\text { b. ló } & \text { wə pa'a } & \text { Tsefor } & \text { (a) } & \text { pe' } & \text { n-dzənə } & \text { ywún páa *(a) } & \text { kojnə } \\ \text { FOC } & \text { who that Tsefor } & \text { SM } & \text { PST } & \text { N-see } & \text { man } & \text { that }\end{array}$

"Who did Tsefor see the man that loves?"

Lit.: 'It is who that Tsefor saw the man that she loves?'

It is probably the pronominal SM in the subject position of the most deeply embedded clause in (i-b) that repairs the island violation. Alternatively, relativization might also involve base-generation of the operator plus binding of a pronoun at the bottom of the dependency. In any case, island-sensitivity is not a sensible diagnostic for movement in Awing. 
Adding the SM to (30) leads to a loss of the 'nobody'-interpretation; only the wide scope reading of the subject NP remains in this case, just as in (29-a). This shows that a SM-doubled subject NP cannot be reconstructed to a position below negation. It can only be interpreted in its high surface position, as expected when the subject NP is base-generated in this position. The same scope pattern is illustrated in (31) for an interaction between an indefinite (bare) subject noun and a universally quantified object NP. As with sentential negation, when the SM is present, the bare noun subject can only take wide scope with respect to the object, see (31-a). In the absence of the SM, the sentence is ambiguous such that either the indefinite subject out scopes the quantified object or vice versa, see (31-b).

a.

\begin{tabular}{|c|c|c|c|c|}
\hline móo-mbyâyn & & $\mathrm{a}$ & pə' & n-tscbo \\
\hline child-man & & SM & PST & $\mathrm{N}$-talk \\
\hline klasə & tênə & tsəmə & & \\
\hline grade & five & all & & \\
\hline
\end{tabular}

'A boy talked to each child in fifth grade.'

Paraphrases:

$\checkmark$ There is a specific boy who talks to each of the children in the fifth grade

*For each child in the fifth grade, there is a (potentially different) boy who talks to this child

b. móo-mbyâynə pə' n-tsebə mbo móo-anwarə klasə ênə tsəmə

child-man PST N-talk to child-school grade five all

'A boy talked to each child in fifth grade.'

$\checkmark$ There is a specific boy who talks to each of the children in the fifth grade

$\checkmark$ For each child in the fifth grade, there is a (potentially different) boy who talks to this child.

Unfortunately, other standard connectivity tests from the literature such as case marking and binding (see e.g., Bresnan and Mchombo 1987; Baker 1996; Alexiadou and Anagnostopoulou1998; Alexiadou 2017; Baker and Kramer 2018) cannot be applied to Awing for independent reasons. ${ }^{15}$ A different test sometimes used to diagnose dislocated topics is an intonation break between the topicalized XP and the rest of the clause. Indeed, such pauses have been reported in several languages in which objects are dislocated and doubled by an object marker (see e.g., Bresnan and Mchombo 1987 on Chichewa). Awing also exhibits these pauses with (contextually identifiable) topics as the one in the example sentence in (25-a). However, similar intonation breaks are absent in declarative sentences with the SM as, e.g., in (1). Though this test does not support our hypothesis, we also do not think that it immediately falsifies it. The same absence of a pause with doubled subjects has been observed in other languages in which these subjects are dislocated by a number of other tests (see, e.g., Baker 2003 on Kinande). There must thus be a different reason for the absence of the pause with dislocated subjects.

To summarize, the absence of semantic connectivity effects with SM-doubled (referential) subjects in declarative clauses provides evidence that these subject NPs are base-generated in their surface position. Undoubled subject NPs, however, do exhibit connectivity effects (viz., can take

\footnotetext{
${ }^{15}$ Base-generated XPs should not be case marked (they have never been in the c-command domain of a case assigner), while moved ones should. Since Awing does not have morphological case, we cannot check this prediction. Another test for doubled objects is binding: If a reflexive pronoun inside a left-peripheral object XP that is doubled by an OM can be bound by the structurally lower subject, it must have been moved. If binding fails, it is base-generated in its surface position. But since Awing doubles subjects and not objects, an equivalent test configuration cannot be created in the first place: the subject could not be bound by the object even if it were reconstructed to its base position in Specv.
} 
low scope) and must thus have undergone movement. This difference between SM- doubled and undoubled subject NPs suggests that sentences with and without the SM must have different derivations (subject NP movement vs. base-generation).

3.3 The structure of clauses with(out) doubled subject NPs. We can now put together the results we have gained so far and provide the structures for sentences like (32) with a transitive verb and a referential subject. Note that we assume that the thematic subject XP in Awing declarative SVO sentences moves from its vP-internal base position to SpecT (EPP-movement) since the thematic subject precedes all temporal and aspectual particles as well as the preverbal part of the negation marker, see all previous examples, e.g., (1). We leave it for future research to determine whether the main verb $\mathrm{V}$ moves all the way up to $\mathrm{T}$; for the sake of concreteness, we only indicate V-to-v-movement in the following structures, but nothing crucial hinges on this for present purposes (see Fominyam and Šimík 2017 for discussion of verb movement in Awing). The TP-structure for the sentence in (32) with the SM is provided in (33) and without the SM in (34). The subject NP is boxed; since the SM is pronominal, we represent it as a D-element: ${ }^{16}$

$\begin{array}{lllll}\text { (32) } & \text { Alombah } & \text { (a) } & \text { nə } & \text { n-nánnə məzí } \\ \text { Alombah } & \text { SM } & \text { PST } & \text { N-cook food }\end{array}$

'Alombah cooked the food.'

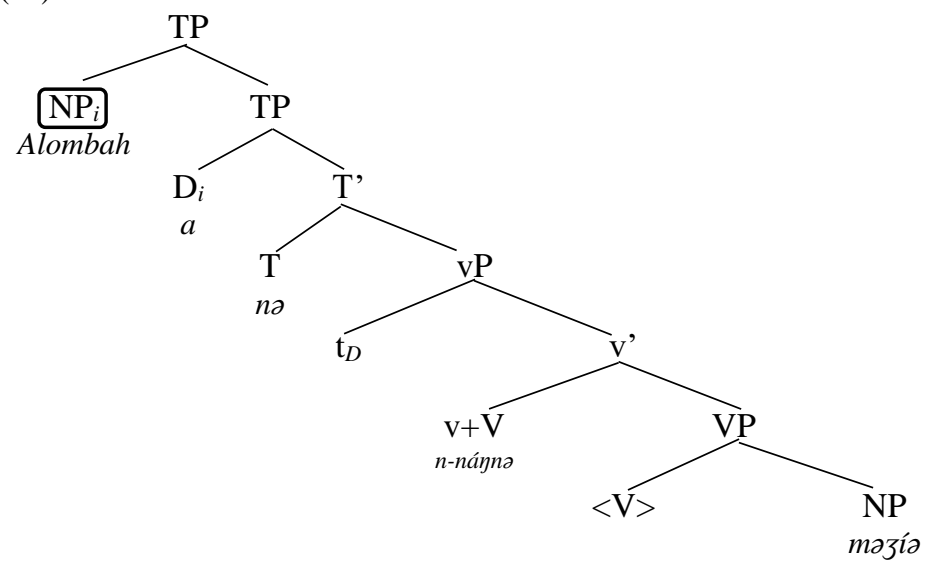

\footnotetext{
${ }^{16}$ We represent nominal arguments as NP instead of DP, but this is just for the sake of concreteness and irrelevant for the main points of this paper. We also leave it for future research to determine whether there are further functional projections in the Awing vP, TP and CP-domain; see Fominyam (in prep.) for discussion.
} 
(34)

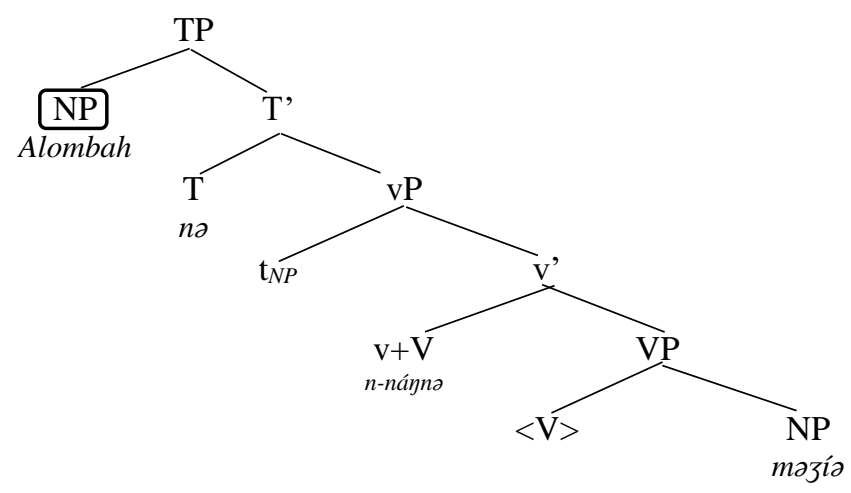

When the subject is doubled by the SM (see (33)), we take the pronominal SM to be the real argument of the verb, i.e., it is the pronoun that is merged in Specv of the transitive verb and is assigned a thematic role in this position (here: the agent-role). Due to the EPP-property, the pronominal SM then moves to SpecT. This accounts for its high position; just like the subject NP in a clause without the SM, it precedes temporal/aspectual and preverbal negation markers. The associated subject NP is base-generated as an adjunct to the TP; it is co-indexed with the SM and binds this pronoun. When the SM is absent (see (34)), the structure is different: In this case, the subject NP functions as the external argument of the transitive verb and receives the agent role. As the structurally highest argument, this NP undergoes EPP-movement to SpecT. Thus, while the subject NP is a base-generated left-peripheral adjunct when the SM is present, it is a thematic argument of the verb in the absence of the SM. This accounts for the differences in the reconstruction potential of the subject NPs with/without the SM presented in section 3.2: Undoubled subject NPs reconstruct to a low vP-internal position, while SM-doubled subjects do not reconstruct. The reason is that doubled subject NPs have never occupied such a low position, they are base-generated at the TP-level. ${ }^{17}$ Put differently, the idea depicted in (33) and (34) is that the subject NP and the SM in Awing compete for being the (in our example external) argument of the verb. If the subject NP is this argument, there is no room left for the SM - the SM could not receive the same theta-role again due to the Theta Criterion (Chomsky 1981). Conversely, if the SM is chosen as the argument of the verb, the subject NP cannot function as the same argument since there is no theta-role available for it anymore; it has already been assigned to the pronominal SM. The subject NP can thus only

\footnotetext{
${ }^{17}$ Unfortunately, we cannot provide additional evidence for the two different positions the subject NPs occupy in the structures in (33) and (34) since the positions are very close, and due to the general properties of Awing syntax. One way to test for structural positions is adverb placement. One might expect, for example, that temporal adverbs left-adjoin to TP; if they target the lower TP in (33), they should follow the subject NP in this structure but precede it in (34). Unfortunately, adjuncts are always confined to the clause final position in Awing (viz. they are right-adjoined), and hence we cannot use them to probe the position of other elements in the clause. Furthermore, there is only left-dislocation in Awing, but no right-dislocation of topic/base-generated NPs that could shed light on their position (compared to argumental NPs). Another argument for (un)doubled objects that is often used to determine whether the object NPs are base-generated adjuncts or arguments is subextraction, cf. the Condition on Extraction Domains according to which only complements are transparent for subextraction (Huang 1982). Thus, adjuncts base-generated in a left-peripheral position should be islands, while complements (direct object arguments) are not islands. However, we are investigating (un)doubled subjects in Awing, and subjects are islands just like adjuncts for the CED, so we would not expect a difference between the subject NPs in (33) and (34) for subextraction in the first place. In addition, we do not think that Awing has wh-/focus movement, as mentioned in section 2.1, hence we do not expect island effects in such dependencies.
} 
function as an adjunct that is semantically linked to the real argument (the SM). Of course, adjunction of the subject NP to TP, as in (33) is not necessary, the sentence is complete (viz., has all the necessary arguments) without this NP. In fact, leaving out the adjoined NP results in a grammatical sentence, viz., a sentence with a pronominal subject as in (24-a), repeated in (35). In this case, the reference of the SM is determined by the discourse (identified with an antecedent previously mentioned in the discourse).

$$
\begin{array}{llll}
\text { a } & \text { nə } & \text { n-náynə } & \text { məzíə } \\
\text { SM } & \text { PST } & \text { N-cook } & \text { food }
\end{array}
$$

'S/he cooked the food.'

Note that this analysis of the SM in Awing is basically equivalent to what Bresnan and Mchombo (1987) have argued for subjects and the SM in Chichewa (Bantu): Either the subject is the true argument of the verb (that agrees with the verb in Chichewa) or it is a topic, viz., a nonargumental element attached at the edge of the clause, that is linked via anaphoric agreement to a pronoun in the subject position. The only difference is that subject NPs as arguments do not agree with the verb in Awing. Baker (2003) makes a similar proposal for subject marking in Kinande (Bantu).

Recall that in a sentence like (32) with a referential subject NP the use of the SM is optional. We take this to mean that the Awing grammar offers both of the structures in (33) and (34), i.e., a base-generation structure and one involving movement of the subject NP to SpecT. Both options are in principle freely available and the speaker can choose one; the choice may be influenced by pragmatic factors (which we will not explore in this paper) but the grammar provides both structures.

Let us now turn to sentences with less/non-referential subjects. For these, the structure in (33) with the SM cannot be used. Why is this the case? In fact, the structure we proposed there provides an answer to this question: It has been observed that crosslinguistically, non-referential nouns (or nouns with low referentiality) are not tolerated in left-adjoined, topic-like positions, which are related to a (resumptive) pronoun (see a.o. Rizzi 1986; 1990; Cinque 1990; Baker 1996; 2003; Alexiadou and Anagnostopoulou 1998; Alexiadou 2017; Baker and Kramer 2018). The SM, as a pronoun, is an anaphoric element whose reference is determined by an antecedent, i.e., by the associated subject NP; to be able to provide a referent for the pronoun, the associated NP will have to be referential itself. Thus, non-referential NPs cannot occur in a left-adjoined position in Awing. In other words, while the structure in (33) is available in the Awing grammar, it is not usable with non-referential subject NPs for independent reasons. In such cases, only the structure in (34) can be used, and the optionality breaks down. Note that even though we have referred to the absence of the SM as "SM-drop" in the beginning, the SM is in fact not dropped (deleted) when it does not occur; it has never been merged into the structure in the first place then.

Finally, we would like to make a few remarks about the structural position of the basemerged subject NP that we postulate in (33). We assume that it is adjoined rather low, viz., to the $\mathrm{TP}$ and not to a more peripheral position, say CP. Evidence for this assumption comes from sentences of the type in (36) where topicalization of a non-subject is combined with a SM-doubled subject NP:

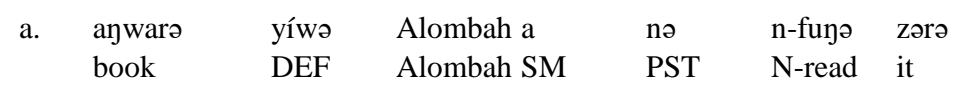




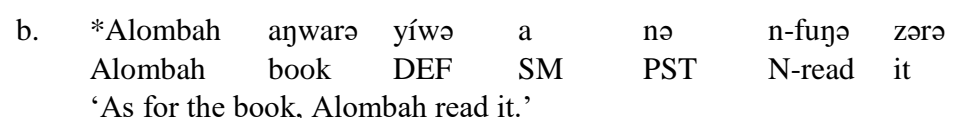

Topics in Awing occur at the left edge of the clause and are resumed by a pronoun in the vP (here by zərə); we take them to be base-generated in the specifier of the CP-domain, for example SpecTop in Rizzi's (1997) split CP-system. Crucially, the subject NP which is doubled by the SM (and hence an adjunct in our analysis) must follow the topic object NP. It must thus adjoin to a position below the TopP; we assume that this adjunction site is the TP. ${ }^{18}$

\section{Consequences}

In this section we discuss consequences of the analysis with respect to post-verbal subjects and pronominal subjects, which may at first seem to be problematic for the present account.

4.1 Post-verbal subjects and the SM. As illustrated above, Awing has basic SVO word order in declarative sentences. However, there is a construction in Awing, identifiable by the occurrence of the morpheme ló, in which subject NPs occur not in a preverbal but rather in a postverbal position. A few examples are given in (37). The construction is used to express exhaustive focus on the subject (see Fominyam and Šimík 2017, who identify lá as an exhaustive focus particle realizing a head above TP; we simply gloss it as FOC here). We imitate this meaning component in the English translation by using a cleft structure; however, it is important to note that the Awing sentences do not contain clefts, they are clearly mono-clausal, see Fominyam and Šimík (2017); Fominyam (2018) for detailed studies of this constructions. ${ }^{19}$
a. lá pe' y-yá' Ayafor y-yá’ə apa yíwə
FOC PST N-open Ayafor N-open bag DEF
'It is Ayafor who opened the bag.'
b. la pe' n-tá n-ndê Neh (n-ndê) afóonə
FOC PST N-PROG N-sleep Neh N-sleep farm
'It is Neh who was sleeping in the farm.'
Fominyam $(2018: 163,165)$

Crucially, in this mono-clausal exhaustive focus construction with postverbal subject NPs, the SM cannot be used. No matter where we put the SM $a$ in the above examples with singular human subjects, the result will always be ungrammatical, as already noted in Fominyam and Šimík

\footnotetext{
${ }^{18}$ Note that the examples in (36) only show that the adjoined subject NP is in a relatively low position, certainly below the position of topics. This position could also be a different one than the TP, especially in a split CP system. An option would, e.g., be FinP. Nothing in our analysis hinges on the exact attachment site of the adjoined subject NP; we just intend to show that it is not in the outermost left-peripheral position.

${ }^{19}$ Fominyam and Šimík (2017) offer a general study of focus marking and focus semantics in Awing. At least new information focus does not have to be marked at all in the language, whereas exhaustive focus requires the ló-construction discussed in the main text. In addition, it is also possible to express exhaustive focus in a biclausal cleft construction that contains a relative clause, but the lo-construction that is the subject of interest for our purposes here is clearly not bi-clausal. See Fominyam (2018) for discussion of the conditions and triggers of verb doubling that occurs in some examples of the mono-clausal lá-construction.
} 
(2017) (their "generalization 3", p.1046) and in Fominyam (2018). ${ }^{20}$ Note that this ban against the SM with postverbal subjects holds regardless of the referentiality of the subject NP, unlike with preverbal subject NPs: In (37) the subject NPs are fully referential, still the SM is blocked. In fact, the postverbal subject NP in this construction can basically be any kind of NP (a wh-pronoun, an (in)definite NP, a personal pronoun, ...), see Fominyam (2018) for examples. In any case, the SM must not occur.

Given that the absence of the SM with postverbal subjects is independent of the subject NP's referentiality - the main factor identified for SM-drop with preverbal subject NPs - the reason for SM-drop in the lá-construction must be a different one. In fact, the analysis of preverbal subjects and the SM outlined in the previous section can account for this prohibition against the SM with postverbal subjects, too.

The crucial observation that is relevant for our explanation is presented in Fominyam (2018) (see his examples (41), (42)): He notes that postverbal subjects occupy their vP-internal base position and have not moved out of the vP (to SpecT) because they necessarily take low scope, e.g., with respect to negation:

$$
\begin{aligned}
& \text { lá pə’ má nán ywún tsəm nán ndzǒ } \\
& \text { FOC PST NEG cook person all cook beans } \\
& \text { V'It is not everybody that cooked beans.' (i.e.e, some cooked something else) } \\
& \text { *'It is everybody that did not cook beans.' (i.e., no one cooked beans) }
\end{aligned}
$$$$
\neg>\forall
$$$$
\forall>\neg
$$

Given that the subject NP is in an A-position inside the vP, it must have been merged there as the argument of the verb, basically as in (34), the only difference being that it has not undergone EPP-movement to SpecT in the lá-construction. ${ }^{21}$ As argued extensively in Fominyam and Šimík (2017), staying inside a low position is necessary for the subject in these sentences in Awing because in general, exhaustively focused XP must be in the c-command domain of the ló-morpheme (and movement might expel the subject from this domain). We argued in the previous section that the SM and the subject NP compete for being the (external) argument of the verb. Thus, if the subject NP is merged as the argument, there is no place left for the SM to be merged, as this would violate the Theta Criterion. Furthermore, even if the SM was merged in some higher position, e.g., in SpecT, the result would be ungrammatical because it would induce a Principle $C$ violation, as schematized in (39):

$$
\left[\operatorname{TP} \operatorname{proi}_{\ldots} \ldots\left[\mathrm{vP} \mathrm{NP}_{\mathrm{i}} \ldots\right]\right]
$$

In such a configuration, the pronominal SM, interpreted as being co-referent with the subject NP, c-commands this NP in Specv. This constitutes a Principle C configuration. Examples of the type in (39) are thus ruled out for the same reason that the sentence in (40) is ungrammatical in Awing (and most other languages): An R-expression is bound by a pronoun.

\footnotetext{
${ }^{20}$ Fominyam and Šimík's (2017) generalization is as follows: "Postverbal subjects never trigger agreement on the verb." They treat the SM as an agreement morpheme, hence the formulation. We have argued in this paper, though, that the SM is in fact a pronominal element.

${ }^{21}$ It is unclear which element satisfies the EPP-property of Awing in sentences with postverbal subjects; see Fominyam (2018) for speculations. This issue is irrelevant for present purposes.
} 


$\begin{array}{llll}\text { a } \quad \text { nə } \quad \text { n-dzənə } & \text { Alombah } \\ \text { SM } \quad \text { PST } & \text { N-see } & \text { Alombah } \\ \text { 'He* }{ }^{*} \text { /j s Saw Alombahi.' } & \end{array}$

The ban on the SM in the lá-construction with post-verbal subjects thus falls out from our analysis without further assumptions. In fact, the observation that postverbal subjects cannot cooccur with preverbal pronominal subject markers has been analyzed as a binding violation before in the literature on Bantu languages, see van der Wal $(2008,2012)$. We adopt this analysis for Awing. ${ }^{22}$

4.2 The ban on pronominal subject doubling. In this section we want to address what might at first seem to be a problem for our account of the SM in Awing. As mentioned in section 3.1, pronominal subjects as in a sentence like 'S/he cooked the food.', see (41), cannot be doubled, i.e., one cannot have the SM doubling/being associated to a pronominal subject (instead of a subject $\mathrm{NP}$ ); this holds for all pronominal subjects in general, not just for the SM $a$.

$\begin{array}{lllll}* a & \text { a } & \text { nə } & \text { n-nájnə məzía } \\ \text { s/he } & \text { SM } & \text { PST } & \text { N-cook food }\end{array}$

Intended: 'S/he cooked the food.'

The question is why this is ruled out. Given our analysis of SM-doubled subjects, the structure should look as in (42) (which corresponds to (33) but with a pronoun adjoined to the TP instead of an NP). Here the boxed D corresponds to the first $a$ in (41), the subject pronoun, and the $\mathrm{D}$ in SpecT represents the SM- $a$ that doubles this subject pronoun:

$$
\left[\operatorname{TP} \mathrm{D}_{\mathrm{i}} \quad\left[\text { Tт } \mathrm{D}_{\mathrm{i}}\left[\mathrm{T}^{\prime} \mathrm{T}\left[\mathrm{vP} \mathrm{t}_{\mathrm{D}}\left[\mathrm{v}^{\prime} \mathrm{v}+\mathrm{V}[\mathrm{vP}<\mathrm{V}>\mathrm{NP}]\right]\right]\right]\right]\right]
$$

The SM is the thematic argument of the verb, merged in Specv and then raised to SpecT (EPP-movement). The associated pronominal subject can then only be an adjunct to TP. The binding principles (here: Principle B) do not rule out this configuration because the adjoined pronoun is not in an A-position. The higher (boxed) pronoun is identified with an antecedent in the discourse, so it should be possible for the SM to co-refer with the adjoined pronoun. Still, the result is ungrammatical. There are in fact two reasons for the ungrammaticality of sentences like (42). The first is that the SM $a$ is a weak (clitic) pronoun and as such cannot occur in a left-dislocated, topiclike position. The table in (43) gives an overview of the weak and strong forms of subject pronouns in Awing (the same weak/strong distinction is found with object pronouns in the language):

\footnotetext{
${ }^{22}$ In fact, van der Wal (2008) makes a distinction between languages where this configuration leads to a Principle C effect and those where it does not (viz., where postverbal subject NPs can co-occur with preverbal subject doubling markers). She argues that in the latter languages (mainly Romance languages in her study) the subject doubling device is an agreement marker and hence no binding violation obtains. In the former languages in which a Principle $\mathrm{C}$ violation arises, the doubling device is a pronoun, however, and hence we get ungrammaticality. The Awing findings we report in this paper fit this description: Postverbal subjects cannot co-occur with a preverbal subject doubling marker because it is a pronoun. Note that given the Principle $\mathrm{C}$ explanation, there is in fact no need to adopt existing formal analyses of the postverbal subject/preverbal SM complementarity in some Bantu languages that derive the effect either from upward Agree or a bundling of the EPP-feature with O-Agree (Collins 2004; Carstens 2005; Baker 2003; 2008b). These additional assumptions are not necessary to explain the complementarity, as van der Wal has pointed out.
} 
(43)

Strong and weak subject pronouns in Awing: ${ }^{23}$
\begin{tabular}{|l|l|l|}
\hline & Weak & Strong \\
\hline $1 \mathrm{sg}$ & $\mathrm{n}$ & man \\
\hline $2 \mathrm{sg}$ & $\mathrm{o}$ & gho \\
\hline $3 \mathrm{sg}$ & $\mathrm{a}$ & yá \\
\hline $1 \mathrm{du}$ & to & pó \\
\hline $1 \mathrm{pl} \mathrm{incl}$ & pəg & \\
\hline $1 \mathrm{pl}$ excl & pen & \\
\hline $2 \mathrm{pl}$ & ná & pí \\
\hline $3 \mathrm{pl}$ & pó & \\
\hline $3 \operatorname{expl}$ & pá & \\
\hline
\end{tabular}

The classification of the elements in the middle column in (43) as weak pronouns is based on their syntactic behavior (see Cardinaletti and Starke 1996; 1999 for tests). Consider the 3sg SM $a$ : It cannot (i) be coordinated with an NP or another pronoun, see (44); ${ }^{24}$ (ii) be modified, e.g., by the focus particle $t s$ ' $^{\prime}$ 'only', see (45); (iii) follow a preposition, see (46); (iv) be used contrastively, see (47); or (v) be used as a fragment answer, see (48).

Coordination:

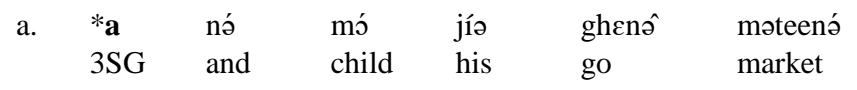

Intended: 'He and his son have gone to the market.'

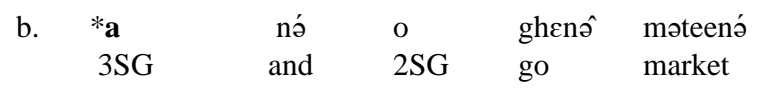

Intended: 'He and you have gone to the market.'

$\begin{array}{rllll}\text { *tsó’ə } & \text { a } & \text { yó } & \text { nánnə } & \text { məkwúnə } \\ \text { only } & \text { 3SG } & \text { FUT } & \text { cook } & \text { rice }\end{array}$

Intended: 'Only he will cook rice.'

(46) *Alombah nə m-fi ndर्ध yíwə mbo a

Alombah PST N-sell house DEF to 3SG

Intended: 'Alombah sold the house to him.'

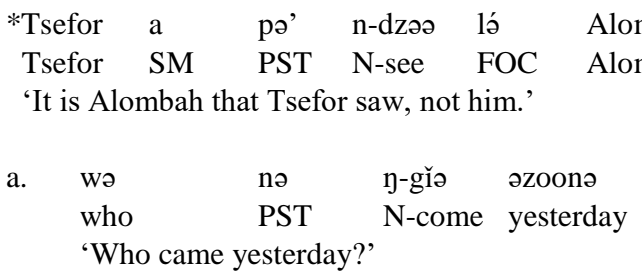

${ }^{23}$ The pronoun labelled '3expl' (= expletive) is not to be confused with the non-human SM $p ə$ in (2). The SM bears a low tone while the 3expl-ponoun bears a high tone and does not refer to anything. Rather, it seems to be an expletive-like element. It is used, e.g., in the subject position of passive clauses in Awing in which the agent is demoted.

${ }^{24}$ To express this content, a commitative phrase at the right edge of the clause has to be used, see (vi), or the corresponding plural pronoun has to be used as the subject ('they') instead of coordination.

$\begin{array}{llllll}\text { (vi) a ghenô } & \text { mateená } & \text { ná } & \text { mó jía } \\ & \text { 3SG } & \text { go } & \text { market } & \text { with child his }\end{array}$

'He goes to the market with his child.' 


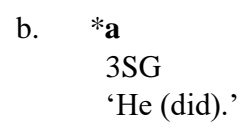

The pronoun that can be used in all of the bold-faced positions (apart from the coordination example, see fns. 20 and 21) is the form yá, the 3sg strong pronoun. ${ }^{25}$ Replacing $a$ by yá in (45) to (48) leads to a grammatical output. And most relevant for present purposes, this strong pronoun can occur as the (adjoined) subject phrase and be doubled by the (weak) SM, when it is followed, e.g., by a relative clause, see (49).

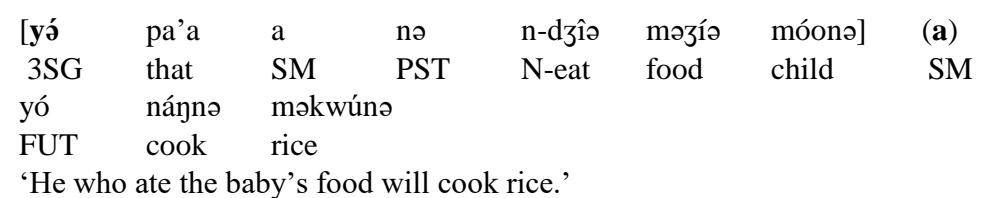

However, this cannot be the whole story, since the presence of the relative clause in (49) is crucial. Just using the strong pronoun as the subject in (49) without the relative is ungrammatical; likewise, replacing the initial $a$ in (41) with the strong form yó does not render the sentence grammatical, see (50).

$\begin{array}{lllll}\text { *yá } & \text { a } & \text { nə } & \text { n-nánnə } & \text { məzíə } \\ \text { 3SG } & \text { SM } & \text { PST } & \text { N-cook } & \text { food }\end{array}$

Intended: 'S/he cooked the food.'

The incompatibility of bare (weak or strong) personal pronoun subjects and the SM holds more generally. We believe that the reason for this incompatibility is the following: In our analysis, SM-doubled subjects are topic-like elements since they are base-generated in the (low) left periphery and resumed by a co-referent pronoun. But personal pronouns in general cannot be topicalized in Awing, not even non-subject ones. Consider the topicalization examples in (51), showing topicalization of NP and pronominal subjects and objects (all of which have to be resumed).
a. Alombah (a) kəyə ykeebə
Alombah SM like money
'Alombah likes money.'
b. Alombah, *(a) kəyə ykeebə Alombah SM like money '(As for) Alombah, he likes money.'
c. jkeebə, Alombah $\quad$ a $\quad$ kəyə *(zərə)
money Alombah like money
'(As for) money, Alombah likes it.'

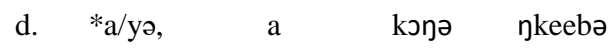
3SG SM love money
Int: '(As for) him, he likes money.'

\footnotetext{
${ }^{25}$ In fact, no pronoun can be used as a conjunct in Awing, not even the strong forms that can occur in the other contexts listed above. Nouns can be conjoined, however. We will have to leave it for future research to determine why pronouns in general resist coordination in Awing.
} 


$\begin{array}{lllll}\text { e. *zərə } & \text { Alombah } & \text { a } & \text { kəyə } & \text { (zərə) } \\ \text { it } & \text { Alombah } & \text { SM } & \text { like } & \text { it } \\ \text { Int: 'As for it, Alombah/he likes it.' } & & \end{array}$

This is probably the case because strong pronouns rather involve focus, for example, they express contrast (see e.g., (47), which is grammatical with the strong pronoun). Thus, our analysis in which doubled subjects have a topic-like function correctly predicts the incompatibility of personal pronouns and the SM, since personal pronouns are rather focal than topical in the language, accounting for the ungrammaticality of (50). In fact, bare strong pronouns can be focused, see (52a). Moreover, they can be relativized, see (52b); relativization makes the pronoun more topical, hence the grammaticality of examples like (49).
$\begin{array}{llllll}\text { a. lá yá } & \text { pá’a } & *(a) & \text { perə } & \text { n-dzé’’ ajwalə } \\ \text { for him } & \text { that } & \text { he } & \text { still } & \text { N-study book }\end{array}$
'It is him who is still going to school.'
b. yá pá'a *(a) perə n-dzé’ə aywalə a yí fúnə aywalə-əsê he that he still N-study book he FUT read book-God 'He who is still going to school will read the bible.'

\section{Conclusion}

In this paper we have studied subject marking in Awing, a Grassfields Bantu language. The SM that can double the subject NP of a sentence expresses the features animacy and number of the subject $\mathrm{NP}$ and is sometimes optional, sometimes prohibited and sometimes obligatory. The aim was to determine the factors that govern the distribution of the SM in Awing. We have argued that the crucial property is the referentiality of the subject rather than its information structural status or whether it bears $\mathrm{A}^{\prime}$-features (properties which have been argued to play an important role in argument marking in other languages): While referential subjects can optionally be accompanied by the SM, less referential or non-referential ones cannot co-occur with the SM. In addition, a subject NP that is doubled by the SM always takes wide scope and receives a specific interpretation; subject NPs without the SM can also take low scope and can have a non-specific reading. Furthermore, we have shown based on a number of tests that the SM in Awing is a weak pronoun rather than an agreement marker. Putting these observations together, we have proposed that the structure of sentences with and without the SM differ in crucial ways: When the SM is present, it is the thematic argument of the verb, while the associated NP is a topic-like adjunct base-generated at the TP-level from where it binds the pronoun. When the SM is not present, however, the subject NP is the thematic argument of the verb and as such is base-merged inside vP before it moves to SpecT to fulfil the EPP. Both structures are in principle available in the Awing grammar. With non-referential subject NPs, however, the adjunct option (where the SM is the thematic argument) is blocked because cross-linguistically, left-dislocated topics have to be referential. Thus, only the second option, i.e., where the subject NP is merged as the thematic argument of the verb, remains. This is what underlies "SM-drop" in Awing. The pronominal nature of the SM also explains why it must be absent when the subject NP stays in its base-position inside the vP, viz., in a post-verbal position (in the lá-construction): When the SM is added and is interpreted as coreferent with the subject NP, this leads to a Principle C violation and is thus ruled out. Obligatory instances of the SM in subject relative clauses are cases in which it functions as a resumptive pronoun. The incompatibility of a pronominal subject and the SM is explained by the topical nature of the position the subject occurs 
in and the fact that personal pronouns cannot be topicalized in Awing. In a nutshell we propose that Awing is a pronominal argument language where subject doubling pronominal elements act as thematic arguments when they are present in a clause (see Jelinek 1984; Bresnan and Mchombo 1987; Baker 1996). The same basic kind of analysis has been proposed for subject and/or object markers in many other languages, especially for Bantu languages, e.g., Haya (Byarushengo et al. 1976), Chichewa (Bresnan and Mchombo 1987), Setswana (Demuth and Mark 1989), and Kinande (Baker 2003); see also Marten and Kula (2012); Zeller (2014); Baker (2018); van der Wal (to appear) and references cited there for an overview of variation in object marking strategies across Bantu languages. Awing shows that the pronominal argument strategy is also used in Grassfields Bantu.

\section{Abbreviations}

$\begin{array}{llll}1 / 2 / 3 & \text { 1st/2nd/3rd person } & \text { INF } & \text { infinitive } \\ \text { C } & \text { complementizer } & \text { ITER } & \text { iterative } \\ \text { DEF } & \text { definite } & \text { L } & \text { linker } \\ \text { DIS } & \text { disjoint marker } & \text { N } & \text { nasal prefix } \\ \text { EMPH } & \text { emphatic } & \text { NEG } & \text { negation } \\ \text { EXPL } & \text { expletive } & \text { PST } & \text { past } \\ \text { FEM } & \text { feminine } & \text { PL } & \text { plural } \\ \text { FOC } & \text { focus } & \text { PROG } & \text { progressive } \\ \text { FUT } & \text { future } & \text { PRTC } & \text { participle } \\ \text { HAB } & \text { habitual } & \text { SG } & \text { singular } \\ \text { IND } & \text { indefinite } & \text { SM } & \text { subject marker }\end{array}$

\section{Acknowledgement}

For comments and discussion of previous versions of this paper we would like to thank the audiences at ACAL 50 (UBC, May 2019) and the DISCO workshop (Leipzig University, May 2019), Radek Šimík, and two anonymous reviewers. This research was funded by the Deutsche Forschungsgemeinschaft (DFG, German Research Foundation) - Project ID 317633480 - SFB 1287, Project C05 (Georgi).

\section{References}

Aguilar-Guevara, Ana, Bert Le Bruyn and Joost Zwarts. 2014. Weak referentiality. Linguistik Aktuell/Linguistics Today 219, Amsterdam: John Benjamins.

Alexiadou, Artemis. 2017: Left dislocation. In: M. Everaert and H. van Riemsdijk, (eds,), The Wiley Blackwell Companion to Syntax, Second Edition. Oxford: Wiley-Blackwell.

Alexiadou, Artemis and Elena Anagnostopoulou. 1998. 'Parametrizing Agr: Word Order, VMovement, and EPP-Checking', Natural Language and Linguistic Theory 16, 491-539.

Alomofor, Christian and Akem, Helen. in prep. The Awing noun class sheet. , Yaoundé, Cameroon: CABTAL.

Alomofor, Christian. 2007. Awing English Dictionary and English-Awing Index. Yaoundé, Cameroon: CABTAL.

Anagnostopoulou, Elena, 2006. Clitic doubling. In: M. Everaert and H. van Riemsdijk, (eds.), The Blackwell companion to syntax Vol. 1. p. 519-581.

Azieshi, Gisele. 1994. Phonologie structurale de l'Awing. MA thesis, Université de Yaoundé I, Cameroon. 
Baier, Nico. 2018. Anti-Agreement. PhD thesis, University of California, Berkeley.

Baier, Nico and Michelle Yuan. 2017. Anti-agreement with Bound Variables. In: W. Bennett, L. Hracs and D. Storoshenko, (eds.), Proceedings of WCCFL 35. Sommerville, MA: Cascadilla Press, pp. 96-103.

Baker, Mark C. 1996. The Polysynthesis Parameter. New York and Oxford: Oxford University Press.

Baker, Mark C. 2003. Agreement, dislocation, and partial configurationality. In: A. Carnie,H. Harley and M.-A. Willie, (eds.), Formal approaches to function in grammar: In honor of Eloise Jelinek, 107-132. Amsterdam: John Benjamins.

Baker, Mark C. 2008a. 'On the Nature of the Antiagreement Effect: Evidence from Wh-in- Situ in Ibibio’, Linguistic Inquiry 39, 615-632.

Baker,Mark C. 2008b. The Syntax of Agreement and Concord. Vol. 115 of Cambridge Studies in Linguistics, Cambridge: Cambridge University Press.

Baker, Mark C. 2018. On the status of object markers in Bantu. In: A. Akinlabi and O. Adesola, (eds.), Data Rich Linguistics: Papers in Honor of Yiwola Awoyale, 2-40. Cambridge: Cambridge Scholars Publishing.

Baker, Mark and Ruth Kramer. 2018. 'Doubled clitics are pronouns: Amharic objects (and beyond)', Natural Language and Linguistic Theory 36(4), 1035-1088.

Belletti, Adriana. 2001. "Inversion" as focalization. In: A. Hulk and J.-Y. Pollock, (eds.), Subject inversion in Romance and the theory of Universal Grammar, 60-90. Oxford: Oxford University Press.

Brandi, Luciana and Patrizia Cordin. 1989. Two Italian dialects and the Null Subject Parameter. In: O. Jaeggli and K. Safir, (eds.), The Null Subject Parameter, 111-142. Kluwer Academic Publishers, Dordrecht.

Bresnan, Joan and Sam A. Mchombo. 1987. 'Topic, Pronoun, and Agreement in Chichewa', Language 63(4), 741-782.

Byarushengo, E. A., Larry Hyman and Sarah Tenenbaum. 1976. Tone, accent, and assertion in Haya. In: L. Hyman, (ed.), Studies in Bantu tonology (Southern California occasional papers in linguistics 3). Department of Linguistics, USC, Los Angeles, 183-205.

Campos, Héctor. 1997. 'On Subject Extraction and the Antiagreement Effect in Romance', Linguistic Inquiry 28, 92-119.

Cardinaletti, Anna and Michal Starke. 1996. Deficient pronouns: a view from Germanic. In: H. Thr'ainsson, S. D. Epstein and P. Steve, (eds.), Studies in comparative Germanic syntax volume II, . 21-65. Kluwer, Dordrecht

Cardinaletti, Anna and Michal Starke. 1999. The Typology of Structural Deficiency: A Case Study of the Three Classes of Pronouns. In: H. Riemsdijk, (ed.), Clitics in the Languages of Europe. 145-235. Berlin: Mouton de Gruyter

Carstens, Vicki. 2005. 'Agree and EPP in Bantu', Natural Language and Linguistic Theory 23, 219 279.

Chen, Ping. 2009. 'Aspects of referentiality', Journal of Pragmatics 41.

Cheng, Lisa Lai-Shen. 2006. Decomposing Bantu Relatives. In: C. Davis, A. R. Deal and Y. Zabbal, (eds.), Proceedings of NELS 36. GLSA, Amherst, Mass, pp. 197-215.

Chomsky, Noam. 1981. Lectures on Government and Binding. Dordrecht: Foris.

Chung, Sandra. 1994. 'Wh-Agreement and 'Referentiality' in Chamorro', Linguistic Inquiry 25, 144.

Cinque, Guglielmo. 1990. Types of A-bar Dependencies. Cambridge, Mass: MIT Press. 
Collins, Chris. 2004. The agreement parameter. In: A. Breitbarth and H. van Riemsdijk, (eds.), Triggers, 115-136. Berlin: Mouton de Gruyter.

Comrie, Bernard. 1989. Language Universals and Linguistic Typology. 2 edn, Oxford: Blackwell.

Corbett, Greville. 2006. Agreement. Cambridge: Cambridge University Press.

Creissels, Denis. 2004. Non-canonical applicatives and focalization in Tswana. Paper presented at the Symposium "Syntax of the World's Languages", Leipzig, August 2004.

Dalrymple, Mary and Irina Nikolaeva. 2011. Objects and information structure. Cambridge: Cambridge University Press.

Demuth, Katherine and Johnson Mark. 1989. 'Interactions between discourse functions and agreement in Setawana', Journal of African Languages and Linguistics 11, 22-35.

Diercks, Michael. 2010. Agreement with subjects in Lubukusu. PhD thesis, Georgetown University, Washington, DC.

Douglas, Jamie. 2017. 'Unifying the that-trace and anti-that-trace effects', Glossa: a journal of general linguistics 2(1), 1-28. DOI: http://doi.org/10.5334/gjgl.312.

Erlewine, Michael Y. 2016. 'Anti-locality and optimality in Kaqchikel Agent Focus', Natural Language and Linguistic Theory 34, 429-479.

Fellbaum, Christiane. 1993. The determiner in English idioms. In: C. Cacciari and P. Tabossi, (eds.), Idioms: processing, structure and interpretation, 271-296. Hillsdale, New Jersey: Erlbaum.

Fodor, Janet Dean and Ivan Sag (1982): 'Referential and quantificational indefinites', Linguistics and Philosophy 5, 355-398.

Fominyam, Henry. 2015. The syntax of focus and interrogation in Awing: A descriptive approach. In: M. Grubic and F. Bildhauer, (eds.), Working Papers of the SFB632 18: Interdisciplinary Studies in Information Structure, 29-62. Potsdam: Universitätsverlag Potsdam.

Fominyam, Henry. 2018. 'Inverting the subject in Awing', Italian Journal of Linguistics 30(2), 159186. DOI: $10.26346 / 1120-2726-128$.

Fominyam, Henry. in prep. Aspects of Awing grammar and information structure. PhD thesis, University of Potsdam, Potsdam.

Fominyam, Henry and Radek Šimík. 2017. 'The morphosyntax of exhaustive focus: A view from Awing (Grassfields Bantu)', Natural Language and Linguistic Theory 35(4), 1027-1077.

Grégoire, Nicole. 2009. Untangling multiword expressions: a study on the representation and variation of Dutch multiword expressions. PhD thesis, University of Utrecht, Utrecht.

Haida, Andreas. 2007. The indefiniteness and focusing of wh-words. PhD thesis, Humboldt University Berlin, Berlin.

Halpert, Claire. 2012. Argument licensing and agreement in Zulu. PhD thesis, MIT, Cambridge, MA.

Heim, Irene. 1982. The Semantics of Definite and Indefinite Noun Phrases. PhD thesis, University of Massachusetts, Amherst.

Henderson, Brent. 2013. 'Agreement and person in anti-agreement', Natural Language and Linguistic Theory 31, 453-481.

Horvath, Julia. 1986. FOCUS in the Theory of Grammar and the Syntax of Hungarian. Dordrecht: Foris.

Huang, Cheng-Teh James. 1982. Logical Relations in Chinese and the Theory of Grammar. PhD thesis, MIT, Cambridge, Mass.

Jelinek, Eloise. 1984. 'Empty Categories, Case, and Configurationality', Natural Language and Linguistic Theory 2, 39-76. 
Kallulli, Dalina. 2000. Direct object clitic doubling in Albanian and Greek. In: F. Beukema and M. den Dikken, (eds.), Clitic phenomena in European languages, 209-248. Amsterdam: John Benjamins.

Karttunen, Lauri. 1968. What Do Referential Indices Refer To. RAND Corporation Report No. P3854, Santa Monica, California.

Keenan, Edward L. and Bernard Comrie. 1977. 'Noun Phrase Accessibility and Universal Grammar', Linguistic Inquiry 8, 63-99.

Klein, Timo. 2016. Patterns of Resumption - Towards a Derivational Account. PhD thesis, Leipzig University.

Kramer, Ruth. 2014. 'Clitic doubling or object agreement: The view from Amharic', Natural Language and Linguistic Theory 32, 593-634.

Lyons, John. 1977. Semantics, Vol. I-II. Cambridge: Cambridge University Press.

Manzini, Rita. 1992. Locality. A Theory and Some of Its Empirical Consequences. Cambridge, MA: MIT Press.

Manzini, Rita and Leonardo Savoia. 2002. Parameters of subject inflection in Italian dialects. In: P. Svenonius, ed., Subjects, expletives, and the EPP, 157-199. Oxford University Press, Oxford.

Marten, Lutz and Nancy C. Kula. 2012. 'Object marking and morphosyntactic variation in Bantu', Southern African Linguistics and Applied Language Studies 30(2), 237-253.

Maxwell, Daniel N. (1979): 'Strategies of Relativization and NP Accessibility', Language: Journal of the Linguistic Society of America 55(2), 352-71.

McCloskey, James. 1990. Resumptive Pronouns, A-Binding and Levels of Representation in Irish. In: R. Hendrick, (ed.), The Syntax of the Modern Celtic Languages, 199-248. San Diego: Academic.

Mucha, Anne and Henry Fominyam. .2017. '(Un-) Restricting Tense in Awing', Proceedings of Triple A 3, 32-46.

Mursell, Johannes. 2018. 'Object marking in Swahili is topic agreement', Jezikoslovlje 19(3), 427455.

Nevins, Andrew. 2007. 'The representation of third person and its consequences for the person-case constraint', Natural Language and Linguistic Theory 25, 273-313.

Nunberg, Geoffrey, Ivan Sag and Thomas Wasow. 1994. 'Idioms', Language 70(3), 491-538. Ouhalla, Jamal (1993): 'Subject-Extraction, Negation and the Antiagreement Effect', Natural Language and Linguistic Theory 11, 477-518.

Partee, Barbara H. 1970. 'Opacity, coreference, and pronouns', Synthese 21, 359-385.

Pesetsky, David. 1987. Wh-in-Situ: Movement and Unselective Binding. In: E. Reuland and A. ter Meulen, (eds.), The Representation of (In)Definiteness, 98-129. Cambridge, MA: MIT Press.

Pesetsky, David. 2000. Phrasal Movement and Its Kin. Cambridge, MA: MIT Press.

Preminger, Omer. 2009. 'Breaking Agreements: Distinguishing Agreement and Clitic Doubling by Their Failures', Linguistic Inquiry 40(4), 619-666.

Rizzi, Luigi. 1986. 'Null Objects in Italian and the Theory of pro', Linguistic Inquiry 17, 501-557. Rizzi, Luigi. 1990. Relativized minimality. Cambridge, Mass: MIT Press.

Rizzi, Luigi. 1997. The Fine Structure of the Left Periphery. In: L. Haegeman, (ed.), Elements of Grammar, 281-337. Dordrecht: Kluwer.

Rizzi, Luigi and Ur Shlonsky. 2007. Strategies of Subject Extraction. In: U. Sauerland and H.-M. G*artner, (eds.), Interfaces + Recursion = Language? Volume 89 of Studies in Generative Grammar, 115-160. Berlin: Mouton de Gruyter. doi:10.1515/9783110207552.115.

Rochemont, Michael. 1986. Focus in Generative Grammar. Amsterdam: John Benjamins. 
Sabel, Joachim. 2000. Partial Wh-Movement and The Typology of Wh-Questions. In: U. Lutz, G. Muller and A. von Stechow, (eds.), Wh-Scope Marking, 409-446. Amsterdam: John Benjamins. Sabel, Joachim and Jochen Zeller. 2006. Wh-question formation in Nguni. In: J. Mugane, J. Hutchison and D. Worman, (eds.), African languages and linguistics in broad perspective, 271283. Cascadilla Press, Somerville.

Safir, Ken. 2017. Weak crossover. In: M. Everaert and H. van Riemsdijk, (eds.), The Wiley Blackwell Companion to Syntax, Second Edition, 1-40. Oxford: Wiley-Blackwell.

Salzmann, Martin. 2017. Reconstruction and Resumption in Indirect $A^{\prime}$-dependencies. On the Syntax of Prolepsis and Relativization in (Swiss) German and beyond. Berlin/Boston: De Gruyter Mouton.

Samek-Lodovici, Vieri. 2002. Agreement Impoverishment under Subject Inversion - A Crosslinguistic Analysis. In: G. Fanselow and C. F'ery, (eds.), Resolving Conflicts in Grammar. Linguistiche Berichte Sonderheft 11, 49-82.

Schneider-Zioga, Patricia. 2000. 'Anti-agreement and the fine structure of the left edge', University of California Irvine Working Papers in Linguistics 6.

Schneider-Zioga, Patricia. 2007. 'Anti-agreement, anti-locality and minimality. The syntax of dislocated subjects', Natural Language and Linguistic Theory 25, 403-446.

Tamanji, Pius N. 2009. A descriptive grammar of Bafut. Cologne: Rüdiger Köppe.

Tuller, Laurice Anne. 1986. Bijective Relations in Universal Grammar and the Syntax of Hausa. $\mathrm{PhD}$ thesis, UCLA, Los Angeles, CA.

van Craenenbroeck, Jeroen, Will Harwood, Marko Hladnik, Sterre Leufkens, Tanja Temmerman and Norbert Corver. 2016. Idioms: phasehood and compositionality.Ms. KU Leuven.

van der Berg, Bianca. 2009. A phonological sketch of Awing. SIL Cameroon, http://www.silcam.org/languages/languagepage.php?languageid=12.

van der Wal, Jenneke. 2008. Agreement in thetic sentences in Bantu and Romance. In: C. De Cat and K. Demuth (eds.), The Bantu-Romance Connection. A comparative investigation of verbal agreement, DPs and information structure, 323-350. Amsterdam: John Benjamins.

van der Wal, Jenneke. 2009. Word order and information structure in Makhuwa-Enahara. PhD thesis, Universiteit Leiden, Leiden.

van der Wal, Jenneke. 2012. 'Subject Agreement and the EPP in Bantu', Cambridge Occasional Papers in Linguistics 6, 201-236.

van der Wal, Jenneke. to appear. The AWSOM correlation in comparative Bantu object marking. In: J. Hartmann, Katharina Mursell and P. W. Smith, (eds.), Agree to agree: Agreement in the Minimalist Program. Open Generative Syntax, Berlin: Language Science Press.

Young, R. 2005. Bantu Comitative and the E-type pronoun. Ms., Cornell University.

Zeller, Jochen. 2008. 'The subject marker in Bantu as an antifocus marker', Stellenbosch papers in linguistics 38, 221-254.

Zeller, Jochen. 2014. 'Three types of object marking in Bantu', Linguistische Berichte 239, 347367.

Zerbian, Sabine. 2006. Expression of information structure in the Bantu language Northern Sotho. $\mathrm{PhD}$ thesis, Humboldt-Universität zu Berlin, Berlin. 
Henry Z. Fominyam < zamchang@uni-potsdam.de $>$

University of Potsdam,

Potsdam, Germany

Doreen Georgi < doreen.georgi@uni-potsdam.de>

University of Potsdam,

Potsdam, Germany 